Does corporate governance influence convertible bond issuance?

January 2013

\author{
Marie Dutordoir \\ Manchester Business School - The University of Manchester \\ Booth Street West, Manchester M15 6PB, UK \\ Marie.Dutordoir@mbs.ac.uk \\ Norman Strong \\ Manchester Business School - The University of Manchester \\ Booth Street East, Manchester M15 6PB, UK \\ Norman.Strong@mbs.ac.uk \\ Marius C. Ziegan* \\ Manchester Business School - The University of Manchester \\ Booth Street West, Manchester M15 6PB, UK \\ Marius.Ziegan@postgrad.mbs.ac.uk
}

We thank Sandra Dow, Alain Praet, Konstantinos Stathopoulos, and participants at the 2012 BAFA annual conference, the FMA 2012 European conference, and the 10th Corporate Finance Day at Ghent University for their valuable comments and suggestions.

* Corresponding Author

Tel: +44-(0)161-3062068, E-mail: Marius.Ziegan@ postgrad.mbs.ac.uk 


\title{
Does corporate governance influence convertible bond issuance?
}

\begin{abstract}
We examine the influence of corporate governance quality on firms' choice between convertible debt, straight debt, and equity using a Western European sample of security offerings made between 2000 and 2010. We find that weaker firm-specific and countryspecific corporate governance quality increases firms' likelihood of issuing convertible debt instead of straight debt and common equity. We also find that stockholder reactions to convertible debt announcements are more favorable for firms with weaker corporate governance. Our results suggest that corporate governance quality is a significant security choice determinant, with firms using convertible debt as a substitute for high quality governance mechanisms.
\end{abstract}

Key words: Security choice; Convertible debt; Corporate Governance

JEL Classification: G32; G34 


\section{Introduction}

In recent decades convertible debt has become a major financing source for companies around the world. However, despite a large body of empirical literature (Billingsley and Smith, 1996; Lewis et al., 1999; Graham and Harvey, 2001; Dutordoir and Van de Gucht, 2009; Dong et al., 2012), firms' motives for issuing convertible debt remain unclear.

Our goal is to examine the impact of firms' corporate governance quality on their likelihood to issue convertible debt instead of straight debt or seasoned equity. The literature on convertible debt issuance motives predicts that convertibles can mitigate agency costs (Green, 1984; Mayers, 1998; Isagawa, 2000) and adverse selection costs resulting from asymmetric information about firm value or risk (Brennan and Kraus, 1987; Brennan and Schwartz, 1988; Stein, 1992). The corporate governance literature, in turn, documents that governance mechanisms can reduce agency and adverse selection costs (Bhojraj and Sengupta, 2003; Anderson et al., 2004; Masulis et al., 2007; Becker-Blease and Irani, 2008).

We combine these two strands of literature to develop predictions on the relation between corporate governance quality and firms' likelihood to issue convertible debt. The Substitution hypothesis predicts that, since convertibles and high quality governance mechanisms are both able to reduce agency and adverse selection costs, firms with lower quality governance in place are more likely to issue convertible bonds instead of straight bonds or equity. In contrast, the Complementarity hypothesis assumes that firms with high quality governance are more likely to adopt financing strategies that further improve shareholder value. Given convertibles' potential to reduce agency and adverse selection costs, this yields the prediction that well governed firms are more inclined to issue convertibles instead of standard nonhybrid financing instruments.

While the Substitution and Complementarity hypotheses rely on the assumption that managers act in shareholders' interests, the Entrenchment hypothesis predicts that entrenched 
managers use convertibles to further insulate themselves from market discipline. We derive this hypothesis from Isagawa's (2002) rationale for convertible bond issuance. Isagawa (2002) argues that, like straight debt, convertible debt reduces the probability of a hostile takeover. However, unlike with straight debt, managers can avoid bankruptcy by forcing conversion of the bonds into equity by calling them. Convertibles may therefore help entrenched managers preserve their control benefits, even if this is not in shareholders' interests. Since managerial entrenchment is likely to be higher in firms with weaker corporate governance (Berger et al., 1997; Bebchuk et al., 2009), the Entrenchment hypothesis predicts a higher likelihood of convertible bond issuance by firms with weaker corporate governance.

Ultimately, therefore, the impact of corporate governance on a company's likelihood to choose convertible debt over standard financing instruments is an empirical question. To examine this question, we use a pan-Western European dataset of 176 convertible issues, 350 straight debt issues, and 141 seasoned equity issues made between 2000 and 2010. The European convertible debt market has experienced dramatic growth in recent decades (Bancel and Mittoo, 2004; Dutordoir and van de Gucht, 2009) and the diversity of European regulatory environments creates a variety of corporate governance systems (Shleifer and Vishny, 1997; Aggarwal et al., 2009), enabling us to consider both internal (companyspecific) and external (country-specific) corporate governance features (Doidge et al., 2007).

We hand collect data for seven internal and four external corporate governance characteristics. We analyze firms' security choices with multinomial logistic regressions including corporate governance measures and a range of firm-specific and macroeconomic control variables. Our focus on incremental security issues allows us to conduct the analysis with independent variables measured prior to security offering announcement dates, which has the advantage of mitigating endogeneity problems inherent to many corporate governance studies. 
Our main results are as follows. Companies with weaker internal and external corporate governance quality are more likely to issue convertible debt than straight debt or seasoned equity. Among corporate governance quality proxies, the impact of the presence of large shareholders is particularly strong. Companies with large shareholders are significantly less likely to issue convertible debt than straight debt and seasoned equity. We also find a significant negative impact of a number of country-specific proxies for corporate governance quality on firms' likelihood of issuing convertible bonds.

The finding that firms with weaker corporate governance are more likely to issue convertible bonds instead of straight debt or equity is consistent with both the Substitution and Entrenchment hypotheses. To discriminate between these two hypotheses, we analyze the impact of corporate governance on stock returns around convertible bond announcements. Consistent with the Substitution hypothesis, we find that stockholders perceive convertibles as more valuable for firms with weaker corporate governance.

Overall, our results indicate that corporate governance characteristics have a statistically and economically significant impact on firms' security choices, and security choice models should therefore incorporate these characteristics.

Our paper contributes to the literature on securities issuance by providing new insights into the so far unresolved question of why firms choose convertible bonds instead of straight bonds or equity. ${ }^{1}$ Our key finding that firms with lower quality corporate governance mechanisms in place are more likely to issue convertibles instead of straight bonds or equity is consistent with theories predicting a role for convertibles in reducing the agency and adverse selection costs associated with non-hybrid financing instruments. In addition, to our knowledge, we are the first to empirically test Isagawa's (2002) rationale for convertible debt issuance.

\footnotetext{
${ }^{1}$ Dutordoir et al. (2012) provide an extensive overview of empirical evidence on firms' motives to issue convertibles. Their overall conclusion is that this evidence is mixed and inconclusive.
} 
Our paper also contributes to the corporate governance literature. While early studies examine individual corporate governance mechanisms in isolation, a more recent stream of articles documents that firms tend to use governance mechanisms as substitutes (e.g., Westphal and Zajac, 1994; Rediker and Seth, 1995; Agrawal and Knoeber, 1996; Singh and Davidson, 2003; Rutherford et al., 2007) or as complements (Danielson and Karpoff, 1998; Cremers and Nair, 2005; Schepker and Oh, 2012). A common feature of these studies is that they focus on traditional corporate governance measures such as board and ownership structure. Our findings suggest that researchers should consider convertible bond issuance as part of a bundle of corporate governance measures that serve to protect shareholder interests (Ward et al., 2009).

The remainder of the paper continues as follows. The next section reviews the relevant literature and develops the hypotheses. Section 3 describes the dataset and discusses the research methodology. Section 4 reports and discusses the empirical results. Section 5 concludes the paper.

\section{Literature review and hypothesis development}

Our hypotheses draw from three strands of literature: studies of the relation between convertible bond issuance and firms' financing costs, studies of the relation between corporate governance and firms' financing costs, and studies of the interdependency between corporate governance mechanisms. In this section, we first briefly review these relevant studies, and then formulate our testable predictions.

\subsection{Convertible bond issuance as a tool to reduce agency and adverse selection costs}

Theories of convertible bond issuance broadly subdivide into two groups. The first, largest group considers convertible debt as a solution to agency conflicts. Jensen (1986), Stulz (1990), and Hart and Moore (1995) argue that straight bonds can mitigate managerial overinvestment by reducing free cash flows and imposing the threat of bankruptcy. Consistent 
with these rationales, Berger et al. (1997), Morellec (2004), and Harvey et al. (2004) obtain empirical evidence suggesting that straight debt acts to reduce management's empire building tendencies. However, as Jensen et al. (1992) and Isagawa (2000) point out, straight debt reduces managerial overinvestment at the expense of creating new agency problems between bondholders and shareholders. This is where convertible debt comes in. Green (1984) shows that convertible debt can mitigate levered firms' shareholder incentives to engage in overly risky projects (the asset substitution problem of Jensen and Meckling, 1976). The underlying intuition is that shareholders share the profits from high risk projects with convertible bondholders, which reduces their incentives to invest in such projects in the first place. Mayers (1998) argues that convertible debt is more suitable than straight debt for financing real investment options. Convertible debt creates less potential for shareholders to engage in harmful overinvestment than do long-term bonds, since the firm can commit to redeem the convertible debt if future investment options have no value. Moreover, the firm saves on the issuing costs of sequential short-term debt offerings because conversion of the convertible bonds creates equity that the firm can use to finance profitable future investment options. Isagawa (2000) presents a formal model showing that convertible debt can tackle both overinvestment and underinvestment incentives (i.e., the debt overhang problem of Myers, 1977). The superiority of convertible debt over straight debt lies in the conversion option design, whereby conversion occurs when outstanding debt causes underinvestment but does not occur when the presence of straight debt prevents managers from overinvesting.

A second group of theories predict that convertibles can alleviate adverse selection costs resulting from asymmetric information. Brennan and Kraus (1987) and Brennan and Schwartz (1988) argue that, because changes in a firm's risk have opposite effects on the value of a convertible's bond and option components, convertible bond value is relatively insensitive to firm risk. As such, convertible debt is a suitable alternative to straight debt when investors 
have difficulty assessing the risk of a company's current and future assets, complicating the determination of an accurate bond yield. Stein (1992) develops a model in which firms use convertibles to mitigate the adverse selection costs resulting from equity financing described by Myers and Majluf (1984), while at the same time avoiding financial distress costs associated with straight bond financing. Existing quantitative and qualitative evidence on the validity of these different convertible bond issuance rationales is mixed and inconclusive (Dutordoir et al., 2012).

Isagawa (2002) relaxes the above models' implicit assumption that convertible bond issuers act in shareholders' interests. His model is based on Zwiebel (1996), who argues that an entrenched manager may prefer straight debt over equity in order to avoid a hostile takeover and the associated loss in control benefits. Straight debt, however, may result in the loss of the manager's control benefits when the firm runs into financial distress. Isagawa (2002) shows that an entrenched manager can avoid both a hostile takeover and bankruptcy by issuing callable convertible debt. As such, callable convertible debt issuance decreases the value of the firm, by allowing managers to make conversion-forcing bond calls when liquidation of the firm would be optimal for shareholders. To our knowledge, the literature has not yet empirically tested the Isagawa rationale.

\subsection{Corporate governance as a tool to reduce agency and adverse selection costs}

Corporate governance deals with the ways in which suppliers of finance to corporations assure themselves of a return on their investment (Shleifer and Vishny, 1997). Many studies suggest that corporate governance mechanisms induce managers to take investment decisions that are in line with shareholders' interests, thereby reducing agency problems. For example, Masulis et al. (2007) find that firms with higher quality governance mechanisms are less likely to engage in value-decreasing acquisitions, and Lin and Chang (2012) document that well governed firms are more likely to engage in successful product introductions. 
A limited number of articles examine the relation between corporate governance quality and adverse selection costs resulting from information asymmetry. Bhojraj and Sengupta (2003) hypothesize that higher quality governance mechanisms reduce information asymmetries between firms and their lenders, leading to lower costs of debt financing. In line with this prediction, they find that firms with greater institutional ownership and stronger outside control of the board enjoy lower bond yields and higher ratings on their new bond issues. Anderson et al. (2004) also find that firms' cost of debt is inversely related to proxies for corporate governance quality. Becker-Blease and Irani (2008) hypothesize that high quality corporate governance mitigates the adverse selection problem described by Myers and Majluf (1984), since shareholders are less worried about managerial opportunism in such firms. Consistent with this prediction, they find that proxies for corporate governance quality attenuate shareholders' negative reaction to seasoned equity offering announcements.

\subsection{The interdependency between governance mechanisms}

A third stream of literature relevant for our study focuses on the interdependency between corporate governance mechanisms. Early research on the determinants and effects of various governance mechanisms typically assumes that these mechanisms operate independently (Danielson and Karpoff, 1998). However, as argued by Gompers et al. (2003) and Chen et al. (2007), among others, separate investigation of individual governance attributes ignores the possibility that these attributes serve as substitutes or complements. The substitution perspective holds that control mechanisms offer alternative ways to incentivize managers and any one mechanism can substitute for another, which is especially relevant when implementing governance measures is costly to the firm (Agrawal and Knoeber, 1996). The literature provides ample empirical evidence for this perspective. For example, Westphal and Zajac (1994) find that the use of long-term CEO incentive plans is negatively related to monitoring processes in place. Other studies documenting substitution effects among 
governance mechanisms include Rediker and Seth (1995), Agrawal and Knoeber (1996), Singh and Davidson (2003), and Rutherford et al. (2007). Conversely, the complementarity perspective holds that any one governance mechanism may be insufficient to reduce firms' agency and adverse selection costs. Principals will seek to implement as many governance mechanisms as possible, inducing synergistic effects, in order to reduce the potential for agent opportunism (Schepker and Oh, 2012). Empirical evidence on this perspective is scarce compared with that for the substitution perspective. Danielson and Karpoff (1998) find that certain governance provisions tend to appear together because management views their effects as complementary. Cremers and Nair (2005) find that internal and external governance mechanisms are complements in being associated with long-term abnormal returns. Schepker and Oh (2012) document complementarity of governance mechanisms in the context of poison pill repeals.

\subsection{Hypotheses}

Together, the above streams of literature suggest the following three testable hypotheses. The Substitution hypothesis predicts that, since convertible bonds and corporate governance mechanisms are alternative ways for firms to achieve lower agency and adverse selection costs, firms use convertible bonds as substitutes for high quality corporate governance. If this hypothesis holds, corporate governance quality measures should have a negative impact on firms' propensity to issue convertibles instead of straight debt or equity. Moreover, if the stock market recognizes the potential of convertible debt to mitigate the higher agency and adverse selection costs associated with poor corporate governance, stock returns around convertible debt announcements should be more favorable for firms with weaker corporate governance. ${ }^{2}$ The substitutive effects of convertibles and traditional governance mechanisms

\footnotetext{
${ }^{2}$ The general finding in the literature is that convertible debt announcements are associated with negative abnormal stock returns that are intermediate in magnitude between those associated with seasoned equity
} 
such as board and ownership structure might result from the documented static nature of these internal governance mechanisms (Gompers et al., 2003; Bebchuk et al., 2009). It may be difficult for firms to change these mechanisms at short notice. Moreover, external (countrywide) governance mechanisms are outside the firms' control. By contrast, firms can structure and issue convertible bonds very quickly (often overnight), and they may therefore provide a flexible and fast way for firms to reduce their agency and adverse selection costs.

The complementarity viewpoint on governance mechanisms inspires our second hypothesis. This viewpoint implies that firms that already have high quality governance mechanisms in place are more inclined to look for further means of reducing agency and adverse selection costs, and issue convertibles as part of a pattern of strong corporate governance. If this hypothesis holds, corporate governance quality measures should have a positive impact on firms' propensity to issue convertibles instead of straight debt or equity. Unlike the two other hypotheses, the Complementarity hypothesis does not yield an explicit prediction on the impact of corporate governance quality on the stock price reaction to convertible bond announcements.

A third hypothesis follows Isagawa's (2002) argument that entrenched managers in companies with weak corporate governance issue convertibles to further secure their positions. If this Entrenchment hypothesis holds, corporate governance quality should have a negative impact on firms' propensity to issue convertibles instead of straight bonds. Moreover, if the market realizes the potential of convertibles to further entrench managers, stock price reactions to convertible debt announcements should be more negative for firms with weaker corporate governance in place.

Table 1 summarizes the three hypotheses by showing the sign of the expected effect of corporate governance quality on firms' propensity to issue convertible debt and on stock

offerings and straight debt offerings (e.g., Dann and Mikkelson, 1984; Mikkelson and Partch, 1986; Lewis et al., 1999). This result is consistent with the adverse selection model of Myers and Majluf (1984). 
returns around convertible bond announcements. It is important to note that our hypotheses regarding short-run announcement returns assume that stockholders are aware of management's motives for issuing convertibles (to protect shareholder interests versus to preserve management's control benefits) at the announcement of these offerings. Moreover, we assume stock markets are informationally efficient (Fama, 1970). That is, stockholders unbiasedly assess the implications of the announced offering and of the associated managerial motives for future cash flows, and the firm's stock price instantaneously reflects this information. Other event studies of the impact of corporate governance measures on stock returns rely on similar assumptions (e.g., Sundaramurthy et al., 1997; Masulis et al., 2007; Lin and Chang, 2012). We do not examine long-term returns following convertible bond issuance due to the methodological problems associated with such an analysis. ${ }^{3}$

\section{Data}

\subsection{Security issues}

We test the hypotheses on a sample of security offerings by firms domiciled in 13 Western European countries, namely Austria, Belgium, Denmark, Finland, France, Germany, Italy, the Netherlands, Norway, Spain, Sweden, Switzerland, and the United Kingdom (UK), between January 2000 and September 2010. The geographical scope of our study follows Dutordoir and Van de Gucht (2007), who identify these countries as the main convertible debt markets in Western Europe.

We download all convertible debt, straight debt, and seasoned equity issues from Thomson ONE Banker. In line with the literature, the sample excludes financial and utility companies and private issues. We aggregate issues offered in several tranches. Applying these criteria gives 593 convertible debt issues, 654 straight debt issues, and 635 seasoned equity issues. From this sample, we retain all issues that meet the following criteria: (1) company

\footnotetext{
${ }^{3}$ Kothari and Warner (1997) discuss the econometric problems associated with long-horizon event studies.
} 
accounts data are available for the fiscal year-end before the issue date; (2) stock price data are available for the year preceding the issue date; and (3) corporate governance data are available for the fiscal year-end before the issue date. Applying these criteria yields a final sample of 176 convertible debt, 350 straight debt, and 141 seasoned equity issues. Table 2 gives the number of convertible debt, straight debt, and equity issues by year and country.

Table 2, panel A shows that the popularity of convertible debt issues varies over time. After eight years of roughly constant convertible debt issues, with an average of around 14 per year, the number drops to four in 2008, the start of the Global Financial Crisis. After 2008 the convertible bond market rebounds with 42 issues in 2009 and 17 in the first nine months of 2010. French firms issue over $40 \%$ of the convertible bonds. Prior studies also document that French issuers dominate the European convertible bond market (Ammann et al., 2003; Bancel and Mittoo, 2004; Dutordoir and Van de Gucht, 2007). ${ }^{4}$ Besides Germany (22 issues), the UK (18 issues), and the Netherlands (15 issues), the remaining countries each have less than ten convertible bond issues.

Panel B shows that the number of straight debt issues is considerably more uniform over the sample period. Issuance is highest in the first two years. After this, the number of issues fluctuates around 30, but drops substantially in 2008. France also accounts for the largest number of straight debt offerings, comprising $30 \%$ of the issues. As with convertible bonds, the next biggest offering nations are Germany (13\%), the UK (10\%), and the Netherlands (8\%), with the remaining countries each contributing less than $10 \%$ of the sample.

Panel $\mathrm{C}$ shows the distribution of seasoned equity issues. There are no equity issues in the first four years of the sample and no more than one offering per year between 2007 and 2009 . These years coincide with equity market downturns caused by the stock market crash at the beginning of the decade and by the Global Financial Crisis. Equity issuance is highest in 2005

\footnotetext{
${ }^{4}$ Robustness checks reported below show that the dominance of French convertibles does not drive our results.
} 
and 2006. ${ }^{5}$ The UK, arguably the most developed equity market in Europe, accounts for almost $40 \%$ of all seasoned equity issues. The next biggest issuing countries are Germany (19\%) and France (8\%). Other countries each contribute less than $7 \%$ of overall equity issues.

\subsection{Proxies for corporate governance quality}

Since corporate governance mechanisms within a firm may work simultaneously and influence each other (Rediker and Seth, 1995), we measure corporate governance quality using a wide range of proxy variables. To measure firm-specific (internal) corporate governance quality, we use the proxy variables below. The first three capture the quality of monitoring of the firm's management, while the last four capture the degree of alignment between managers' and shareholders' interests. Table 3 provides precise definitions of all the variables in the study and their data source.

Ownership concentration: Blockholders are assumed to actively monitor management and thereby enhance corporate governance quality because they can more easily bear the costs of collecting information on management's behavior than can smaller shareholders (Stiglitz, 1985). Unreported analyses of the ownership characteristics of our security samples indicate that for convertible debt and equity, the average equity ownership percentage falls below 5\% for the fourth largest shareholder. For straight debt, this happens for the third largest shareholder. ${ }^{6}$ An equity ownership of $5 \%$ is widely considered to be the threshold for considering a shareholder as "large" (i.e., a blockholder) (e.g., Agrawal and Knoeber, 1996; Cremers and Nair, 2005; Cronqvist and Fahlenbrach, 2009). Our first ownership concentration measure, labeled ownership concentration (1), therefore measures the percentage of shares held by the company's three largest shareholders. Several other studies use this measure, e.g., Mehran (1992), La Porta et al. (1998), and Rossi and Volpin (2004).

\footnotetext{
${ }^{5}$ Robustness checks reported below show that the clustering of offerings in 2005 and 2006 does not drive our results.

${ }^{6}$ Results of untabulated analyses reported throughout the paper are available from the corresponding author.
} 
We construct an alternative ownership concentration measure (ownership concentration (2)) equal to the percentage of shares held by the company's largest shareholder. Rediker and Seth (1995) and Voulgaris et al. (2010), among others, use an equivalent measure.

Outside directors: Outside directors are members of the board who are not and never have been company employees. We assume they are better monitors of management, since their human capital is not tied to the firm (Rosenstein and Wyatt, 1990; Agrawal and Knoeber, 1996). We use the percentage of independent board members as our measure for this variable.

Board size: Board size is the total number of directors on the company's board. Several studies show that larger boards are inefficient monitors of management due to free-rider problems, resulting in lower firm performance (Yermack, 1996; Conyon and Peck, 1998; Core et al., 1999).

CEO tenure: CEO tenure is the number of years the CEO has held that position in the firm. Berger et al. (1997) argue that CEOs with longer tenure in a firm may be more entrenched, leading to lower corporate governance quality. Moreover, Murphy (1986) finds that CEO tenure is negatively correlated with managerial pay-performance sensitivity. The reason is that there is greater information asymmetry about CEO ability at the beginning of a contract, leading companies to rely more on performance-based compensation. ${ }^{7}$

CEO age: Gibbons and Murphy (1992) and Palia (2001) find that CEOs closer to retirement receive a significantly larger portion of stock options and performance-based compensation in their salary contracts. Career concerns incentivize the performance of younger managers, reducing the need for such contracts. This means that CEO age can proxy for performance-based compensation. Managers' interests coincide more closely with those of outside shareholders the larger their equity stakes (Jensen and Meckling, 1976). Everything

\footnotetext{
${ }^{7}$ We do not have data on executive compensation packages for European companies.
} 
else equal, therefore, an older CEO should translate into a higher manager-shareholder alignment and better corporate governance quality.

Founder CEO dummy: Founding CEOs typically own substantially larger equity stakes in their companies than non-founding CEOs, resulting in greater alignment with shareholder interests (Adams et al., 2010). ${ }^{8}$

Outside CEO dummy: CEOs hired from outside the firm have less time to accumulate large stockholdings in the company, making their interests less aligned with those of shareholders.

We measure all of these firm-specific governance characteristics at the fiscal year-end before the convertible bond's issue date. We collect blockholder information from Thomson ONE Banker and Orbis. The other six internal characteristics are mostly hand collected from BoardEx. As BoardEx coverage is not sufficient for all companies and years, we supplement BoardEx data with data from company reports, capital market filings, and newspaper articles.

The legal system, culture, and institutional framework of the country of domicile of security issuers may also affect corporate governance quality (Cremers and Nair, 2005; Doidge et al., 2007; Aggarwal et al., 2009). As external measures of corporate governance, we consider shareholder and creditor rights using the anti-director rights and creditor rights indices of La Porta et al. (1998). Both indices capture the legal framework for good corporate governance with a higher score on the index indicating better external governance. We follow Korkeamaki (2005) and use dummy variables taking a value of one for index scores of four or higher for the anti-directors rights index, and three or higher for the creditor rights index.

Hostile takeovers are another channel of external monitoring. If a company performs poorly due to managerial opportunism or inefficiency, it is more likely to become a hostile takeover target with its managers being either replaced or better monitored (Jensen, 1986).

\footnotetext{
${ }^{8}$ We do not have direct data on managerial stock ownership for European companies.
} 
One condition for takeovers to be a successful control mechanism is a liquid capital market. We therefore include proxies for a country's stock market and credit market development, in line with Korkeamaki (2005). Stock market development is domestic stock market capitalization deflated by GDP. Credit market development is total private domestic claims deflated by GDP. Both variables are measured at the fiscal year-end before the issue and obtained from EuroMonitor.

Table 4 reports descriptive statistics for the corporate governance characteristics of the convertible debt, straight debt, and seasoned equity samples. Panel D tests pairwise differences in means between the convertible debt sample and the other two security samples. The two ownership concentration measures show that, on average, European security issuers have concentrated ownership structures, with average shareholdings of the largest shareholder (as captured by ownership concentration (2)) of the order of $20 \%$, and average shareholdings of the three largest shareholders (as captured by ownership concentration (1)) of the order of $30 \%$. But convertible bond issuers, on average, have significantly less concentrated ownership structures than straight debt or equity issuers. Assuming that blockholders are more effective at monitoring management, this result is consistent with companies with weaker corporate governance relying more on convertible debt. We also find that convertible debt issuers have CEOs with significantly longer tenure than straight debt and equity issuers. Furthermore, convertible debt issuers have a significantly higher percentage of outside CEOs than straight debt issuers. Finally, a significantly lower percentage of convertible debt issuers than equity issuers have founder CEOs. On the whole, these findings support the Substitution and Entrenchment hypotheses, predicting a negative relation between corporate governance quality and convertible bond issuance.

However, we also obtain some support for the Complementarity hypothesis, as convertible issuers have a higher percentage of outside directors than straight debt and equity 
issuers, as well as significantly older CEOs than equity issuers. The finding that convertible issuers have significantly smaller boards than straight debt issuers, but significantly larger boards than seasoned equity issuers, provides mixed evidence.

For the external channels of corporate governance, convertible issuers, on average, come from countries with lower shareholder and creditor rights protection and less developed capital markets.

Most of the univariate findings are thus consistent with the Substitution and Entrenchment hypotheses, predicting a negative impact of corporate governance quality on firms' likelihood to issue convertible debt.

\subsection{Firm-specific control variables}

Besides corporate governance characteristics, we control for firm-specific characteristics affecting the choice between convertibles, straight debt, and equity. In line with Dutordoir and Van de Gucht (2007), we group the firm-specific characteristics into proxies for equity-related adverse selection costs, proxies for debt-related financing costs, and proxies for general financing costs. Table 3 provides a detailed description of the measurement and data sources for these variables. All control variables are measured prior to the security issue date.

\subsubsection{Proxies for equity-related financing costs}

According to the adverse selection framework of Myers and Majluf (1984), the announcement of equity-like financing may signal that the firm is overvalued, leading to a negative stock price reaction to the offering announcement. We expect a negative impact of proxies for the magnitude of this equity-related adverse selection effect on firms' likelihood of choosing more equity-like securities. Lucas and McDonald (1990) argue that the equityrelated adverse selection problem is likely to be smaller for firms with a large stock price runup before the issue, since stockholders may interpret the run-up as a signal of good investment projects. However, the pre-offering stock price run-up may also proxy for firm overvaluation 
and, as such, be associated with higher equity-related financing costs. As Myers and Majluf (1984) argue, equity-related adverse selection costs may be higher for firms with more financial slack available. Such firms could have used internal funds instead and are therefore more likely to be perceived as overvalued. Following Krasker (1986), equity-related adverse selection costs should be higher for larger issues. As equity-related adverse selection cost proxies, we therefore include the pre-offering stock price run-up, financial slack over total assets, and the ratio of offering proceeds to the market value of common equity.

\subsubsection{Proxies for debt-related financing costs}

Our analysis also includes a number of debt-related financing cost proxies suggested by capital structure theories. We include the ratio of income taxes to total assets as an inverse debt-related cost measure. This ratio captures the extent to which firms can exploit the tax deductibility of debt interest payments (Modigliani and Miller, 1963). We include return on assets (ROA), as high profitability before the issue makes it easier for a company to pay interest on debt securities (Lewis et al., 1999). We expect a negative impact of these inverse debt-related financing cost proxies on firms' likelihood to issue more equity-like securities.

To measure firms' financial distress costs, we include short- and long-term debt to total assets and stock return volatility. We include short-term debt in addition to long-term debt since, due to its maturity, high short-term debt may be a better indicator of financial distress than high long-term debt (Diamond, 1991). Leverage and stock return volatility can also proxy for asset substitution costs (Green, 1984) and stock return volatility can capture risk uncertainty (Brennan and Schwartz, 1988). We predict a positive impact of these debt-related financing cost proxies on firms' likelihood to choose relatively more equity-like securities.

\subsubsection{Proxies for general financing costs}

In addition to specific equity- and debt-related financing cost measures, we include a number of widely used control variables that can capture a range of financing costs. Since 
these variables can proxy for both debt-related and equity-related financing costs, we do not have clear predictions on their impact on firms' propensities to choose more equity-like securities. In particular, we control for a company's total assets, market-to-book-ratio, and sales growth. Total assets may proxy for the magnitude of asymmetric information and financial distress costs (Lewis et al., 1999). The market-to-book ratio may proxy for the availability of profitable growth opportunities, resulting in lower external financing costs. On the other hand, high growth firms tend to suffer from higher asymmetric information related to their value and risk and from debt-related underinvestment problems (Myers, 1977), increasing their external financing costs. A similar ambiguous interpretation holds for sales growth, an alternative growth measure in our analysis.

\subsection{Macroeconomic control variables}

As argued by Choe et al. (1993) and Bayless and Chaplinsky (1996), financing costs vary not only at the firm level but also at a macroeconomic level. We therefore include several widely used macroeconomic financing cost proxies in our analysis (e.g., Lewis et al., 1999; Dutordoir and Van de Gucht, 2009; Frank and Goyal, 2009). We expect a positive (negative) impact of macroeconomic debt-related (equity-related) financing cost proxies on firms' propensity to issue more equity-like securities.

As an inverse proxy for the economy-wide level of equity-related financing costs, we include the stock market run-up. Stock market volatility and the five-year German Treasury bond yield act as proxies for the economy-wide level of debt-related financing costs. A sixmonth European leading indicator acts as an inverse proxy for external financing costs in general, as it measures economy-wide growth opportunities. Table 3 provides a more detailed description of the measurement and data sources for these macroeconomic control variables. Stock market run-up and volatility are measured over a $(-200,-20)$ window before issuance 
and the Treasury bond yield and leading indicator are calculated over the quarter prior to the issue month.

Table 5 reports descriptive statistics for the firm-specific and macroeconomic control variables for the three security samples. Panel D gives $t$-statistics for pairwise differences in means between the convertible sample and the other two security samples.

For the equity-related financing cost proxies, convertible debt issuers have a significantly larger stock price run-up than straight debt issuers, and a significantly smaller (larger) ratio of financial slack to total assets than straight debt (equity) issuers. These findings are in line with our predictions. However, we also find a significantly larger offering proceeds ratio for convertible debt issuers than for straight debt issuers, which is not in line with our expectations. For the debt-related financing cost measures, convertible debt issuers have significantly smaller income tax to total assets than straight debt issuers, significantly smaller (higher) ROAs than straight debt (equity) issuers, and significantly larger (smaller) stock return volatility than straight debt (equity) issuers. These results are in line with our predictions. But we also find that convertible bond issuers have significantly higher short- and long-term leverage than equity issuers, which is unexpected. For the general financing cost measures, convertible bond issuers have significantly smaller (larger) total assets than straight debt (equity) issuers, significantly lower market-to-book ratios than equity issuers, and significantly higher sales growth than straight debt issuers.

As expected, compared to equity, convertible debt issues are less likely following stock market run-ups and more likely when Treasury bond yields are high. Convertible bond issues are associated with higher values of stock market volatility and the 6-month leading indicator than straight debt and equity issues. Not in line with theory is a lower likelihood of convertible bond issues compared to straight debt when Treasury bond yields are high. 
In conclusion, the control variable descriptive statistics are largely in line with our predictions and confirm that convertible bond issuers tend to have high costs of both straight debt and equity financing.

To check for multicollinearity problems, we analyze pairwise Pearson correlations between the corporate governance characteristics and between the corporate governance characteristics and the control variables. The results of this untabulated analysis indicate that correlations do not exceed 0.42 and are below 0.3 for the large majority of variables.

\section{Empirical results}

In a first step of our security choice analysis, we test whether the independence of irrelevant alternatives (IIA) assumption holds among firms' choices between convertible debt, straight debt, and seasoned equity. The IIA property means that the log odds ratio of any two alternatives in the security choice menu does not depend on the availability of the third. If this assumption holds, we can estimate the choice between the three financing options with a multinomial logit model (Train, 2009). If it does not hold, we have to resort to a nested model specification. A Hausman test indicates that the IIA assumption is not violated in our dataset, leading us to opt for a multinomial logit analysis. ${ }^{9}$ The output of the multinomial logit model consists of two pairwise regressions: one that models firms' likelihood to choose straight debt over convertibles (set as the base outcome) and one that models firms' likelihood to choose seasoned equity over convertibles. Tables 6 and 7 report the results of these two pairwise regressions. For ease of interpretation, we reverse the coefficient signs in the regressions so that the coefficients represent firms' likelihood to choose convertibles (the base outcome) instead of straight debt (Table 6) or seasoned equity (Table 7). We stress that these pairwise regression results are the outcome of a multinomial security choice model that simultaneously

\footnotetext{
${ }^{9}$ Erel et al. (2012) use a similar approach in their security choice analysis.
} 
incorporates all three security types (667 offerings in total), since firms are likely to consider the three financing options simultaneously in reality.

To further determine the validity of our hypotheses, we examine the effects of detailed ownership characteristics on security choices (Table 8) and the effects of corporate governance on convertible debt announcement returns (Table 9). The remainder of this section discusses the results of these analyses in more detail. We also outline a number of robustness tests.

\subsection{The choice between convertible and straight debt}

Table 6 reports the results of the multinomial logit analysis of the determinants of firms' choice between convertible debt and straight debt. We take the natural logarithm of ownership concentration (1), board size, CEO tenure, and CEO age. ${ }^{10}$

Regression (1) reports results for the security choice model using only control variables on the right-hand side. The results are largely consistent with our predictions and with the univariate results. In particular, convertible debt issuers have a significantly larger stock price run-up, long-term debt ratio, stock return volatility, sales growth and stock market volatility, and significantly smaller issue proceeds and total assets than straight debt issuers.

Regression (2) extends regression (1) by adding the internal and external corporate governance characteristics. We find a significant negative impact of ownership concentration (1) on the likelihood of issuing convertible debt over straight debt. This result supports the Substitution and Entrenchment hypotheses. ${ }^{11}$ Also in line with these hypotheses is a significant positive impact of the outside CEO dummy variable on the likelihood to issue

\footnotetext{
${ }^{10}$ We use this transformation in all subsequent regression models.

${ }^{11}$ Several studies find evidence that the impact of ownership concentration on firms' corporate governance quality becomes negative when ownership concentration is very high (e.g., Morck et al., 1988; Claessens et al., 2002). In unreported robustness tests, we include squared values of the ownership concentration measures to test for a concave impact. We find that the squared ownership concentration measures are never significant and that other results are robust to their inclusion.
} 
convertible debt. Findings on the impact of external corporate governance characteristics also support these hypotheses. In particular, the creditor rights dummy variable and stock market development both have a significant negative impact on firms' likelihood to issue convertible debt. Credit market development has a weakly significant positive impact, in line with the Complementarity hypothesis. A $\chi^{2}$-test of the joint significance of the corporate governance variables gives a value of 75.54 , significant at less than $1 \%$.

The remaining regressions provide a number of robustness tests. Regression (3) substitutes ownership concentration (2) (capturing the shareholding of the largest shareholder) for ownership concentration (1) (capturing the shareholding of the three largest shareholders). Regression (4) includes a dummy variable taking the value one for offerings made during 2005 and 2006 to control for the clustering of security issues in these years. The findings remain the same for both regressions. Regression (5) adds a dummy variable taking the value one for French security issues, thereby controlling for the possibility that the dominance of French convertible debt issues drives the results. The regression shows a significant positive impact of this dummy variable, whilst the findings on the impact of corporate governance characteristics are largely consistent with those in previous regressions. ${ }^{12}$ The only difference is that the creditor rights variable is now insignificant.

The impact of corporate governance characteristics on firms' trade-off between convertible debt and straight debt is economically significant. An untabulated analysis of the marginal effects of the significant corporate governance determinants (evaluated at the variable means) shows that a $1 \%$ increase in the ownership concentration (2) measure reduces the likelihood of a convertible debt issue by $0.4 \%$. The presence of an outside CEO, in turn,

\footnotetext{
${ }^{12}$ The significant positive impact of the French dummy variable on firms' likelihood to issue convertible debt instead of straight debt is consistent with the popularity of convertible debt in France documented by several previous studies (Ammann et al., 2003; Bancel and Mittoo, 2004; Dutordoir and Van de Gucht, 2007) as well as by business press articles (Wright, 2000; de Teran, 2001).
} 
increases the likelihood of a convertible debt issue by $12 \%$. Finally, for companies from countries with strong creditor protection or a more developed stock market, the likelihood of a convertible debt issue falls by $14 \%$ and $31 \%$, respectively.

Regression (6) tests the robustness of our results to using internal and external corporate governance indices based on the seven internal and four external corporate governance variables. We construct these indices following the methodology of Maskara and Mullineaux (2011) in developing their information asymmetry index. We determine the quintile of each continuous corporate governance measure, calculate the quintile average across both internal and external continuous variables, and add the values of dummy variables to the quintile averages. We find a significant negative impact for both indices, corroborating our evidence for the Substitution and Entrenchment hypotheses.

\subsection{The choice between convertible debt and seasoned equity}

In this section we examine the impact of corporate governance quality on firms' propensity to issue convertible debt instead of equity. The Substitution (Complementarity) hypotheses predict a negative (positive) impact of corporate governance quality proxies on firms' propensity to issue convertible debt instead of equity. The Entrenchment hypothesis does not yield a prediction on the choice between convertible debt and equity, as it perceives convertible debt as an alternative to straight debt. Table 7 reports the results.

Regression (1) includes only control variables on the right hand side. The findings are mostly consistent with our predictions. We find a significant negative impact of income taxes to total assets and the leading indicator, and a significant positive impact of stock market runup, Treasury bond yields, and stock market volatility on firms' likelihood to issue convertibles instead of equity. We also find a significant positive impact of total assets.

Regression (2), which includes the different governance quality attributes, shows that firms characterized by weaker corporate governance, as proxied by lower values of ownership 
concentration (1), shareholder rights, and creditor rights, have a significantly higher likelihood of issuing convertible debt instead of equity.

Regression (3) shows results using ownership concentration (2) instead of ownership concentration (1). The findings remain the same. Regression (4) controls for issues clustered in 2005 and 2006, while regression (5) controls for French issues. In both cases the results remain mostly unchanged. Most important, the significant negative impact of ownership concentration and shareholder rights remains intact. The only difference is that the creditor rights variable loses its significant negative impact.

The marginal effects of the significant corporate governance variables evaluated at the variable means (not tabulated) show that a $1 \%$ increase in ownership concentration (2) reduces the likelihood of a convertible debt issue by $0.5 \%$, and that coming from a country with strong creditor protection reduces this likelihood by $33 \%$.

Regression (6) examines the security choice using the two corporate governance indices instead of the separate corporate governance variables. A significant negative impact of the external governance quality index on the propensity to issue convertible bonds confirms the previous findings.

Overall, these results suggest that corporate governance quality has an economically significant, negative impact on firms' likelihood to issue convertibles instead of seasoned equity.

\subsection{Detailed analysis of blockholder categories}

In this subsection, we explore whether the negative impact of ownership concentration on firms' likelihood to issue convertible debt instead of non-hybrid securities is robust across ownership categories. Cronqvist and Fahlenbrach (2009) provide evidence that blockholders are heterogeneous in terms of beliefs, skills, and preferences. Most relevant for our research are differences in the strength of monitoring activity across blockholder categories. We expect 
blockholder categories with stronger monitoring incentives to have a stronger positive impact on firms' corporate governance quality, and therefore a stronger impact on firms' choice between convertible debt and other security types.

Using Orbis and Thomson ONE Banker, we classify each blockholder into one of the following ten categories: banks, financial advisory firms, foundations, governments, hedge funds/private equity firms, industrials, insurance companies, management, mutual funds, and private (mostly family) owners. Among the ten categories, we expect foundations and private owners to have the strongest monitoring incentives due to their limited wealth diversification. Following Thomsen et al. (2006) who study corporate ownership in Europe, we create dummy variables taking the value one if a particular blockholder category owns at least $10 \%$ of the company's shares at the fiscal year-end before the offering announcement date. Using these dummy variables, we re-estimate the multinomial logit model to test whether the negative impact of blockholders is robust across different blockholder types. Table 8 reports the results.

For the propensity to issue convertible debt instead of straight debt, the results show that foundations, governments, and private owners have a significant negative impact on the likelihood of issuing convertible debt. The results on foundations and private owners are consistent with these blockholder types having strong incentives to monitor firms. All other categories, besides banks (significantly positive), have an insignificant impact on this choice. The impact of all other corporate governance characteristics and control variables is similar to the results obtained with the aggregate ownership concentration measures.

For the propensity to issue convertible debt instead of equity, financial advisory firms, governments, and private owners have a significant negative impact, while the coefficients on the other blockholder categories are insignificant. The significant negative effect of 
governments and private owners is in line with their monitoring incentives resulting in a strong link with corporate governance quality.

\subsection{Stock returns around convertible debt announcements}

The security choice analysis suggests that companies with weaker corporate governance are more likely to issue convertible bonds. This result could stem either from convertible debt being used to reduce financing costs (the Substitution hypothesis) or from convertible debt being issued by entrenched managers (the Entrenchment hypothesis). To disentangle these two explanations, this section examines announcement returns of convertible debt issues. If the Substitution hypothesis holds, companies with weak corporate governance use convertible debt to reduce external financing costs. If stockholders acknowledge this motivation, we should observe a more favorable stock price reaction to convertible debt announcements by issuers with weaker governance quality, since convertibles are more useful for these firms. Conversely, if entrenched managers issue convertible debt to further insulate themselves from market forces and stockholders are aware of this motivation, we should observe a less favorable reaction to convertible debt announcements by weak governance issuers. To examine which prediction holds, we regress cumulative abnormal returns (CARs) calculated using a single factor market model on corporate governance characteristics and control variables. We estimate the market model over trading days -300 to -46 relative to the announcement date. Following Lease et al. (1991) and Abhyankar and Dunning (1999) we calculate CARs over a $(0,1)$ window to allow for announcements occurring on day 0 after the close of trade. We use the same corporate governance and control variables as in the logistic regressions following Jung et al. (1996) and Lewis et al. (1999), who argue that a theory of corporate security choice should explain both the choice itself and the stock market reaction to the security choice announcement. Table 9 shows the results of these regressions. 
Regression (1) uses the corporate governance and control variables as independent variables. Consistent with the Substitution hypothesis, the results show a significant negative impact of the founder CEO dummy variable and of creditor rights. To further disentangle the Substitution and Entrenchment hypotheses, regression (2) includes a dummy variable taking the value one if the convertible bonds are callable. If the Entrenchment hypothesis holds, callable convertibles should yield more negative stockholder reactions since conversionforcing bond calls might allow entrenched managers to avoid bankruptcy even if liquidation would be optimal for the firm (Isagawa, 2002). As we are now considering convertible bond design, we also include the convertibles delta in the regression for completeness. Delta is the sensitivity of the convertible bond value with respect to the underlying stock value at the announcement date. A higher delta indicates a more equity-like convertible bond. Delta is calculated as

$$
\Delta=e^{-\delta T} N\left(d_{1}\right)=e^{-\delta T} N\left(\frac{\ln (S / X)+\left(r-\delta+T \sigma^{2} / 2\right)}{\sigma \sqrt{T}}\right)
$$

where $\delta$ is the continuously compounded dividend yield for the fiscal year end preceding the announcement date, $T$ is the initial convertible debt maturity (in years), $S$ is the price of the underlying stock measured seven days before the announcement date, $X$ is the conversion price, $r$ is the continuously compounded yield on a five-year German Treasury bond (measured on the announcement date), and $\sigma$ is the annual stock return volatility.

The regression results show insignificant impacts of the call dummy and delta on announcement returns. The founder CEO dummy and creditor rights variables keep their significant negative impacts. We thus conclude that the significant results in the announcement returns analysis are consistent with the Substitution rather than the Entrenchment hypothesis. Overall, only a few variables have a significant impact on convertible bond announcement returns. This low explanatory power is probably attributable 
to the high noise to signal ratio of daily abnormal stock returns. Other studies in the literature also obtain poor explanatory power for regressions explaining stock price reactions to security offering announcements (e.g., Lewis et al., 1999; Dutordoir and Hodrick, 2012).

\section{Conclusion}

We examine the impact of corporate governance quality on firms' choice between convertible debt, straight debt, and equity. We formulate three hypotheses on the potential impact of corporate governance quality on convertible bond issuance and announcement returns, and test these hypotheses on a sample of Western European security offerings made between 2000 and 2010.

Our main finding is that companies with weaker corporate governance are significantly more likely to issue convertible debt than straight debt or seasoned equity. Our results on internal corporate governance mechanisms indicate a significant negative impact of corporate blockholders on the convertible bond choice. This result mainly holds for blockholders with strong monitoring incentives. The strong impact of blockholders on corporate security choices is in line with findings of other studies on corporate governance in Europe. For example, Drobetz et al. (2004) argue that US firms, which traditionally have highly dispersed ownership, rely mainly on the legal protection of minority investors, the monitoring role of boards, and the market for corporate control to reduce agency conflicts. By contrast, German firms rely heavily on the monitoring role of blockholders. We also find a significant negative impact of several country-specific proxies for corporate governance quality on firms' propensity to issue convertible debt. The results are robust to measuring corporate governance quality through composite indices rather than with individual proxies. Our analysis suggests that future models of corporate security choice should control for both internal and external (country-specific) corporate governance quality proxies. 
To further disentangle whether the security choice is consistent with shareholder value maximization (the Substitution hypothesis) or management entrenchment (the Entrenchment hypothesis), we analyze stock returns around convertible bond announcements. In line with the former hypothesis, we find that convertible debt announcement returns are negatively influenced by some measures of corporate governance quality. Our results thus paint a favorable image of firms' motives for using convertible debt. That is, firms seem to use convertibles to achieve lower agency and adverse selection costs, rather than as an entrenchment mechanism. A potential reason for the lack of evidence for Isagawa's (2002) entrenchment rationale in our data is that we focus on a Western European setting. It would be interesting to verify the validity of this rationale for a sample of security issues in emerging markets, where managers and families routinely employ pyramid ownership structures to give themselves control rights that far exceed their proportional cash flows (Harvey et al., 2004). A priori, we would expect to obtain more evidence for an entrenchment rationale on security issuance in such a context. 


\section{References}

Abhyankar, A. and Dunning, A., 1999. Wealth effects of convertible bond and convertible preference share issues: An empirical analysis of the UK market. J. Bank. Financ. 23, $1043-1065$.

Adams, R.B., Hermalin, B.E. and Weisbach, M.S., 2010. The role of boards of directors in corporate governance: A conceptual framework and survey. J. Econ. Lit. 48, 58-107.

Aggarwal, R., Erel, I., Stulz, R. and Williamson, R., 2009. Differences in governance practices between U.S. and foreign firms: Measurement, causes, and consequences. Rev. Financ. Stud. 22, 3171-3209.

Agrawal, A. and Knoeber, C.R., 1996. Firm performance and mechanisms to control agency problems between managers and shareholders. J. Financ. Quant. Anal. 31, 377-397.

Ammann, M., Kind, A. and Wilde, C., 2003. Are convertible bonds underpriced? An analysis of the French market. J. Bank. Financ. 27, 635-653.

Anderson, R.C., Mansi, S.A. and Reeb, D.M., 2004. Board characteristics, accounting report integrity, and the cost of debt. J. Account. Econ. 37, 315-342.

Bancel, F. and Mittoo, U.R., 2004. Why do European firms issue convertible debt? Eur. Financ. Manage. 10, 339-373.

Bayless, M. and Chaplinsky, S., 1996. Is there a window of opportunity for seasoned equity issuance. J. Financ. 51, 253-278.

Bebchuk, L., Cohen, A. and Ferrel, A., 2009. What matters in corporate governance? Rev. Financ. Stud. 22, 783-827.

Becker-Blease, J.R. and Irani, A.J., 2008. Do corporate governance attributes affect adverse selection costs? Evidence from seasoned equity offerings. Rev. Quant. Financ. Acc. 30, 281-296.

Berger, P., Ofek, E. and Yermack, D., 1997. Managerial entrenchment and capital structure decisions. J. Financ. 52, 1411-1438.

Bhojraj, S. and Sengupta P., 2003. Effect of corporate governance on bond ratings and yields:

The role of institutional investors and outside directors. J. Bus. 76, 455-475.

Billingsley, R.S. and Smith, D.M., 1996. Why do firms issue convertible debt? Financ. Manage. 25, 93-99.

Brennan, M.J. and Kraus, A., 1987. Efficient financing under asymmetric information. J. Financ. 25, 1225-1243. 
Brennan, M.J. and Schwartz, E.S., 1988. The case for convertibles. J. Appl. Corp. Financ. 1, $55-64$.

Chen, A., Kao, L., Tsao, M. and Wu, C., 2007. Building a corporate governance index from the perspectives of ownership and leadership for firms in Taiwan. Corp. Gov. 15, 251261.

Choe, H., Masulis, R.W. and Nanda, V., 1993. Common stock offerings across the business cycle: Theory and evidence. J. Empir. Financ. 1, 3-31.

Claessens, S., Djankov, S., Fan, J.P.H. and Lang, L.H.P., 2002. Disentangling the entrenchment and incentive effects of large shareholdings. J. Financ. 57, 2741-2771.

Conyon, M.J. and Peck, S.I., 1998. Board size and corporate performance: Evidence from European countries. Eur. J. Financ. 4, 291-304.

Core, J.E., Holthausen, R.W. and Larcker, D.F., 1999. Corporate governance, chief executive officer compensation, and firm performance. J. Financ. Econ. 51, 371-406.

Cremers, K.J.M. and Nair, V.B., 2005. Governance mechanisms and equity prices. J. Financ. 60, 2859-2894.

Cronqvist, H. and Fahlenbrach, R., 2009. Large shareholders and corporate policies. Rev. Financ. Stud. 22, 3941-3976.

Danielson, M.G. and Karpoff, J.M., 2006. Do pills poison operating performance? J. Corp. Financ. 12, 536-559.

Dann, L.Y. and Mikkelson, W.H., 1984. Convertible debt issuance, capital structure change and financing-related information: Some new evidence. J. Financ. Econ. 13, 157-186.

de Teran, N., 2001. French flair and sophistication dominate European market. The Financial News, 12/02/2001.

Diamond, D.W., 1991. Debt maturity structure and liquidity risk. Q. J. Econ. 106, 709-737.

Doidge, C., Karolyi, G.A. and Stulz, R.M., 2007. Why do countries matter so much for corporate governance? J. Financ. Econ. 86, 1-39.

Drobetz, W., Schillhofer, A. and Zimmermann, H., 2004. Corporate governance and expected stock returns: Evidence from Germany. Eur. Financ. Manag. 10, 267-293.

Dong, M., Dutordoir, M. and Veld, C., 2012. Why do firms issue convertible bonds? Evidence from the field. Working Paper.

Dutordoir, M. and Hodrick, L.S., 2012. Self-selection and stock returns around corporate security offering announcements. Working Paper.

Dutordoir, M., Lewis, C.M., Seward, J.K. and Veld, C., 2012. What we do and do not know about convertible bond financing. Working Paper. 
Dutordoir, M. and Van de Gucht, L., 2007. Are there windows of opportunity for convertible debt issuance? Evidence for Western Europe. J. Bank. Financ. 31, 2828-2846.

Dutordoir, M. and Van de Gucht, L., 2009. Why do Western European firms issue convertibles instead of straight debt or equity? Eur. Financ. Manage. 15, 563-583.

Erel, I., Julio, B., Kim, W. and Weisbach, M.S., 2012. Macroeconomic conditions and capital raising. Rev. Financ. Stud. 25, 341-376.

Fama, E.F., 1970. Efficient capital markets: A review of theory and empirical work. J. Financ. $25,383-417$.

Frank, M.Z and Goyal, V.K., 2009. Capital structure decisions: Which factors are reliably important? Financ. Manage. 38, 1-37.

Gibbons, R. and Murphy, K.J., 1992. Optimal incentive contracts in the presence of career concerns. Theory and evidence. J. Polit. Econ. 88, 468-505.

Gompers, P., Ishii, J. and Metrick, A., 2003. Corporate governance and equity prices. Q. J. Econ. 118, 107-156.

Graham, J.R. and Harvey, C.R., 2001. The theory and practice of corporate finance: Evidence from the field. J. Financ. Econ. 60, 187-243.

Green, R.C., 1984. Investment incentives, debt and warrants. J. Financ. Econ. 13, 115-136.

Hart, O. and Moore, J., 1995. Debt and seniority: An analysis of the role of hard claims in constraining management. Am. Econ. Rev. 85, 567-585.

Harvey, C.R., Lins, K.V. and Roper, A.H., 2004. The effect of capital structure when expected agency costs are extreme. J. Financ. Econ. 74, 3-30.

Isagawa, N., 2000. Convertible debt: An effective instrument to control managerial opportunism. Rev. Financ. Econ. 9, 15-26.

Isagawa, N., 2002. Callable convertible debt under managerial entrenchment. J. Corp. Financ. $8,255-270$.

Jensen, M.C., 1986. Agency costs of free cash flows, corporate finance and takeovers. Am. Econ. Rev. 76, 323-329.

Jensen, G.R., Solberg, D.P. and Zorn, T.S., 1992. Simultaneous determination of insider ownership, debt, and dividend policies. J. Financ. Quant. Anal. 27, 247-261.

Jensen, M.C. and Meckling W.H., 1976. Theory of the firm: Managerial behavior, agency costs and ownership structure. J. Financ. Econ. 3, 305-360.

Jung, K., Kim, Y-C. and Stulz, R.M., 1996. Timing, investment opportunities, managerial discretion, and the security issue decision. J. Financ. Econ. 42, 159-186. 
Korkeamaki, T.P., 2005. Effects of law on corporate financing practices - international evidence from convertible bond issues. J. Corp. Financ. 11, 809-831.

Kothari, S.P. and Warner, J.B., 1997. Measuring long-horizon security price performance. F. Financ. Econ. 43, 301-339.

Krasker, W.S., 1986. Stock price movements in response to stock issues under asymmetric information. J. Finance 41, 93-105.

La Porta, R., Lopez-de-Silanes, F., Shleifer, A. and Vishny, R.W., 1998. Law and finance. J. Polit. Econ. 106, 1113-1155.

Lease, R.C., Masulis, R.W. and Page, J.R., 1991. An investigation of market microstructure impacts on event study returns. J. Finance 46, 1523-1536.

Lewis, C.M., Rogalski, R.J. and Seward, J.K., 1999. Is convertible debt a substitute for straight debt or for common equity? Financ. Manage. 28, 5-27.

Lin, W.C. and Chang, S.C., 2012. Corporate governance and the stock market reaction to new product announcements. Rev. Quant. Financ. Account. 39, 273-291.

Lucas, D.J. and McDonald, R.L., 1990. Equity issues and stock price dynamics. J. Financ. 45, 1019-1043.

Maskara, P.K. and Mullineaux, D.J., 2011. Information asymmetry and self-selection in bank loan announcement studies. J. Financ. Econ. 101, 684-694.

Masulis, R.W., Wang, C. and Xie, F., 2007. Corporate governance and acquirer returns. J. Financ. 62, 1851-1889.

Mayers, D., 1998. Why firms issue convertible bonds: The matching of financial and real investment options. J. Financ. Econ. 47, 83-102.

Mehran, H., 1992. Executive incentive plans, corporate control, and capital structure. J. Financ. Quant. Anal. 27, 539-560.

Mikkelson, W.H. and Partch, M.M., 1986. Valuation effects of security offerings and the issuance process. J. Financ. Econ. 15, 31-60.

Morck, E., Shleifer, A. and Vishny, R.W., 1988. Management ownership and market valuation: An empirical analysis. J. Financ. Econ. 20, 293-315.

Modigliani, F. and Miller, M.H., 1963. Corporate income taxes and the cost of capital: A correction. Am. Econ. Rev. 53, 433-443.

Morellec, E., 2004. Can managerial discretion explain observed leverage ratios? Rev. Financ. Stud. 17, 257-294.

Murphy, K.J., 1986. Incentives, learning and compensation. A theoretical and empirical investigation of managerial labor contracts. Rand J. Econ. 17, 59-76. 
Myers, S.C., 1977. Determinants of corporate borrowing. J. Financ. Econ. 5, 147-175.

Myers, S.C. and Majluf, N.S., 1984. Corporate financing and investment decisions when firms have information that investors do not have. J. Financ. Econ. 13, 187-221.

Palia, D., 2001. The endogeneity of managerial compensation in firm valuation: A solution. Rev. Financ. Stud. 14, 735-764.

Rediker, K.J. and Seth, A., 1995. Boards of directors and substitution effects of alternative governance mechanisms. Strategic Manage. J. 16, 85-99.

Rosenstein, S. and Wyatt, J.G., 1990. Outside directors, board independence and shareholder wealth. J. Financ. Econ. 26, 175-191.

Rossi, S. and Volpin, P.F., 2004. Cross-country determinants of mergers and acquisitions. J. Financ. Econ. 74, 277-304.

Rutherford, M.A., Buchholtz, A.K. and Brown, J.A., 2007. Examining the relationship between monitoring and incentives in corporate governance. J. Manage. Stud. 44, 414430.

Schepker, D.J. and Oh, W.Y., 2012. Complementary or substitutive effects? Corporate governance mechanisms and poison pill repeal. Forthcoming J. Manage.

Shleifer, A. and Vishny, R.W., 1997. A survey of corporate governance. J. Finance 52, 737783.

Singh, M. and Davidson, W.N.III., 2003. Agency costs, ownership structure and corporate governance mechanisms. J. Bank. Financ. 27, 793-816.

Stein, J.C., 1992. Convertible bonds as backdoor equity financing. J. Financ. Econ. 32, 3-21.

Stiglitz, J.E., 1985. Credit markets and the control of capital. J. Money Credit Bank. 17, 133152.

Stulz, R.M., 1990. Managerial discretion and optimal financing policies. J. Financ. Econ. 26, $3-27$.

Sundaramurthy, C., Mahoney, J.M. and Mahoney, J.T., 1997. Board structure, antitakeover provisions and stockholder wealth. Strategic Manage. J. 18, 231-245.

Thomsen, S., Pedersen, T. and Kvist, H.K., 2006. Blockholder ownership: Effects on firm value in market and control based governance systems. J. Corp. Financ. 12, 246-269.

Train, K., 2009. Discrete choice models with simulation, $2^{\text {nd }}$ Ed. Cambridge University Press. Voulgaris, G., Stahopoulos, K. and Walker M., 2010. Compensation consultants and CEO pay. Corp. Gov. 18, 511-526. 
Ward, A.J., Brown, J.A. and Rodriguez, D., 2009. Governance bundles, firm performance, and the substitutability and complementarity of governance mechanisms. Corp. Gov. 17, 646-660.

Westphal, J.D. and Zajac, E.J., 1994. Substance and symbolism in CEOs' long-term incentive plans. Admin. Sci. Quart 39, 367-390.

Wright, W., 2000. Gallic excellence in convertibles. The Financial news, 10/07/2000.

Yermack, D., 1996. Higher market valuations for firms with a small board of directors. J. Financ. Econ. 40, 185-211.

Zwiebel, J., 1996. Dynamic capital structure under managerial entrenchment. Am. Econ. Rev. $86,1197-1215$. 
Table 1

Predicted impact of corporate governance quality on the choice to issue convertibles and on stock returns around convertible debt announcements

This table reports the expected impact of corporate governance quality on the choice to issue convertible debt compared with both debt and equity, and on convertible debt announcement returns. The Substitution hypothesis predicts a substitution effect between convertible debt and corporate governance quality. The Complementarity hypothesis predicts a complementary relationship between convertible debt and corporate governance quality. The Entrenchment hypothesis follows Isagawa (2002) and predicts that, compared to straight debt, convertible debt is used by firms with entrenched managers (weaker corporate governance) to secure their positions. CD is convertible debt, SD straight debt, and SE seasoned equity.

\begin{tabular}{lcccc}
\hline Rationale & \multicolumn{3}{c}{ Impact of corporate governance quality on } \\
& CD vs. SD & CD vs. SE & Announcement returns \\
\hline Substitution hypothesis & - & - & - \\
Complementarity hypothesis & + & + & No prediction \\
Entrenchment hypothesis & - & No prediction & + \\
\hline
\end{tabular}


Table 2

\section{Descriptive statistics for security issues}

The table reports the number of issues by year and by country, along with percentages, for samples of convertible debt (panel A), straight debt (panel B), and seasoned equity (panel C) issues offered by industrial companies from 13 European countries between January 2000 and September 2010. Data on all issues are from Thomson ONE Banker.

\begin{tabular}{|c|c|c|c|c|c|}
\hline Issue year & Number of issues & Percentage & Country & Number of issues & Percentage \\
\hline \multicolumn{6}{|c|}{ Panel A: Convertible debt issues } \\
\hline 2000 & 7 & 3.95 & Austria & 9 & 5.11 \\
\hline 2001 & 14 & 7.91 & Belgium & 3 & 1.70 \\
\hline 2002 & 14 & 7.91 & Denmark & 0 & 0.00 \\
\hline 2003 & 19 & 10.73 & Finland & 3 & 1.70 \\
\hline 2004 & 15 & 8.47 & France & 73 & 41.48 \\
\hline 2005 & 14 & 7.91 & Germany & 22 & 12.50 \\
\hline 2006 & 9 & 5.08 & Italy & 6 & 3.39 \\
\hline 2007 & 21 & 12.43 & Netherlands & 15 & 8.52 \\
\hline 2008 & 4 & 2.26 & Norway & 5 & 2.84 \\
\hline 2009 & 42 & 23.73 & Spain & 8 & 4.52 \\
\hline 2010 & 17 & 9.60 & Sweden & 5 & 2.84 \\
\hline \multirow[t]{3}{*}{ Total } & 176 & 100.00 & Switzerland & 9 & 5.11 \\
\hline & & & United Kingdom & 18 & 10.22 \\
\hline & & & Total & 176 & 100.00 \\
\hline \multicolumn{6}{|c|}{ Panel B: Straight debt issues } \\
\hline 2000 & 41 & 11.71 & Austria & 7 & 2.00 \\
\hline 2001 & 54 & 15.43 & Belgium & 8 & 2.29 \\
\hline 2002 & 37 & 10.57 & Denmark & 3 & 0.86 \\
\hline 2003 & 31 & 8.86 & Finland & 7 & 2.00 \\
\hline 2004 & 34 & 9.71 & France & 101 & 28.86 \\
\hline 2005 & 34 & 9.71 & Germany & 43 & 12.29 \\
\hline 2006 & 19 & 5.43 & Italy & 16 & 4.57 \\
\hline 2007 & 24 & 6.86 & Netherlands & 27 & 7.71 \\
\hline 2008 & 11 & 3.14 & Norway & 4 & 1.14 \\
\hline 2009 & 36 & 10.29 & Spain & 2 & 0.57 \\
\hline 2010 & 29 & 8.29 & Sweden & 15 & 4.29 \\
\hline \multirow[t]{3}{*}{ Total } & 350 & 100.00 & Switzerland & 41 & 11.71 \\
\hline & & & United Kingdom & 76 & 21.71 \\
\hline & & & Total & 350 & 100.00 \\
\hline \multicolumn{6}{|c|}{ Panel C: Equity issues } \\
\hline 2000 & 0 & 0.00 & Austria & 2 & 1.42 \\
\hline 2001 & 0 & 0.00 & Belgium & 1 & 0.71 \\
\hline 2002 & 0 & 0.00 & Denmark & 3 & 2.13 \\
\hline 2003 & 0 & 0.00 & Finland & 8 & 5.67 \\
\hline 2004 & 7 & 4.96 & France & 12 & 8.51 \\
\hline 2005 & 78 & 55.32 & Germany & 27 & 19.15 \\
\hline 2006 & 44 & 31.21 & Italy & 3 & 2.13 \\
\hline 2007 & 1 & 0.71 & Netherlands & 8 & 5.67 \\
\hline 2008 & 0 & 0.00 & Norway & 6 & 4.26 \\
\hline 2009 & 1 & 0.71 & Spain & 1 & 0.71 \\
\hline 2010 & 10 & 7.09 & Sweden & 9 & 6.38 \\
\hline \multirow[t]{3}{*}{ Total } & 141 & 100.00 & Switzerland & 5 & 3.55 \\
\hline & & & United Kingdom & 56 & 39.72 \\
\hline & & & Total & 141 & 100.00 \\
\hline
\end{tabular}


Table 3

Variable descriptions

This table defines the corporate governance (panel A) and control variables (panel B) and their data sources. Within each category, variables are in alphabetical order. All variables are measured at the end of the fiscal year before the security offering, unless noted otherwise.

\begin{tabular}{|c|c|c|}
\hline Variable & Definition & Source \\
\hline
\end{tabular}

Board size

CEO age

CEO tenure

Credit market development

Creditor rights

External governance quality index

\section{Founder CEO}

Internal governance quality index

Outside CEO

Outside directors

Ownership concentration (1)
Total number of directors on the company's board

Age of the company's CEO

Number of years the company's $\mathrm{CEO}$ has been in office

Sum of all private domestic claims divided by the GDP of the issuing firm's country of domicile

Dummy variable taking the value one for countries with a creditor rights index of three or above

Quintile average across all external continuous corporate governance variables plus the value of external dummy variables

Dummy variable taking the value one if the CEO is the founder of the company

Quintile average across all internal continuous corporate governance variables plus the value of internal dummy variables

Dummy variable taking the value one if the CEO was hired from outside the company and was never an employee of the company

Percentage of independent board members (directors who are not and have never been employed by the company) relative to the total number of board members

Percentage of shares held by the company's three largest shareholders
BoardEx, company reports

BoardEx, company reports, capital market filings, newspaper articles

BoardEx, company reports, capital market filings, newspaper articles

Euromonitor

La Porta et al. (1998)

External corporate governance variables

BoardEx, company reports, newspaper articles

Internal corporate governance variables

BoardEx, company reports, capital market filings, and newspaper articles

BoardEx, company reports

Orbis, Thomson ONE Banker 
Table 3 (continued)

Ownership concentration (2)

Shareholder rights

Stock market development

Panel B: Control variables

Delta

Financial slack/total assets

Income tax/total assets

Leading indicator

Long-term debt/total assets

Market-to-book ratio

Return on assets (\%)

Sales growth $(\%)$

Short-term debt /total assets

Stock market run-up

Stock price run-up

Stock return volatility
Percentage of shares held by the company's largest shareholder

Dummy variable taking the value one for countries with an antidirector rights index score of four or above

Stock market capitalization divided by the GDP of the issuing firm's country of domicile

Sensitivity of the bond with respect to the underlying stock value at the announcement date

Net operating cash flow minus cash dividends minus capital expenditures over the book value of total assets

Income taxes paid over the book value of total assets

Six-month European leading indicator calculated as the log growth rate over the quarter preceding the issue month

Book value of long-term debt over the book value of total assets

Market value of equity over the book value of equity

EBIT over the value of total assets

Growth in sales in the fiscal year before the security issue

Book value of short-term debt over the book value of total assets

Return on the MSCI European equity market index over the window $(-200,-20)$

Cumulative daily stock return over the window 76 to 2 trading days before the security issue

Annualized stock return volatility based on daily stock returns measured over the fiscal year before the security issue
Orbis, Thomson ONE

Banker

La Porta et al. (1998)

Euromonitor

Thomson ONE Banker, Datastream

Worldscope

Worldscope

Datastream

Worldscope

Worldscope

Worldscope

Worldscope

Worldscope

Datastream

Datastream

Datastream 
Table 3 (continued)

Stock market volatility

Treasury bond yield

Total assets $(\log )$

Total proceeds/market value
Return volatility of the MSCI

European equity market index

over the window $(-200,-20)$

Average yield on 5-year German Treasury bonds, over the quarter preceding the issue month

Logarithm of the book value of total assets (millions USD)

Total proceeds of the security issue over market value of equity
Datastream

Datastream

Worldscope

Thomson ONE Banker, Datastream 
Table 4

\section{Descriptive statistics for corporate governance characteristics}

This table reports descriptive statistics for the corporate governance characteristics of companies in the convertible debt (panel A), straight debt (panel B), and equity (panel C) samples. Panel D reports $t$-statistics for pairwise differences in means of the corporate governance characteristics between convertible debt (CD) and straight debt and convertible debt and seasoned equity issuing firms. Table 3 gives the definition and source of all variables. $+(-)$ next to a variable name indicates it is a proxy (inverse proxy) for corporate governance quality. $* * *$, and $* * *$ denote significance at the $0.10,0.05$, and 0.01 levels.

\begin{tabular}{|c|c|c|c|c|c|}
\hline Variable & Mean & Median & Std. Dev. & Min. & Max. \\
\hline \multicolumn{6}{|l|}{ Panel A: Convertible debt issues } \\
\hline Ownership concentration (1) $(\%)(+)$ & 33.47 & 29.44 & 20.54 & 0.99 & 88.83 \\
\hline Ownership concentration $(2)(\%)(+)$ & 19.92 & 14.51 & 16.67 & 0.57 & 81.49 \\
\hline Outside directors $(+)$ & 0.32 & 0.33 & 0.23 & 0.00 & 0.80 \\
\hline Board size $(-)$ & 12.91 & 12.00 & 5.45 & 3.00 & 29.00 \\
\hline CEO tenure (years) $(-)$ & 5.91 & 4.05 & 6.31 & 0.10 & 35.80 \\
\hline CEO age $(+)$ & 53.26 & 53.00 & 7.55 & 32.00 & 73.00 \\
\hline Outside CEO (-) & 0.35 & 0.00 & 0.48 & 0.00 & 1.00 \\
\hline Founder CEO $(+)$ & 0.09 & 0.00 & 0.28 & 0.00 & 1.00 \\
\hline Shareholder rights $(+)$ & 0.18 & 0.00 & 0.38 & 0.00 & 1.00 \\
\hline Creditor rights $(+)$ & 0.28 & 0.00 & 0.45 & 0.00 & 1.00 \\
\hline Stock market development $(+)$ & 0.84 & 0.74 & 0.51 & 0.13 & 3.10 \\
\hline Credit market development $(+)$ & 1.18 & 1.08 & 0.36 & 0.75 & 2.14 \\
\hline \multicolumn{6}{|l|}{ Panel B: Straight debt issues } \\
\hline Ownership concentration $(1)(\%)(+)$ & 33.27 & 30.50 & 21.93 & 1.61 & 93.00 \\
\hline Ownership concentration $(2)(\%)(+)$ & 22.54 & 17.00 & 19.19 & 0.64 & 90.15 \\
\hline Outside directors $(+)$ & 0.30 & 0.31 & 0.23 & 0.00 & 0.90 \\
\hline Board size $(-)$ & 15.06 & 14.00 & 5.43 & 3.00 & 30.00 \\
\hline CEO tenure (years) $(-)$ & 5.20 & 3.70 & 4.82 & 0.10 & 32.00 \\
\hline CEO age $(+)$ & 53.46 & 54.00 & 7.21 & 30.00 & 83.00 \\
\hline Outside CEO (-) & 0.24 & 0.00 & 0.42 & 0.00 & 1.00 \\
\hline Founder CEO (+) & 0.08 & 0.00 & 0.27 & 0.00 & 1.00 \\
\hline Shareholder rights $(+)$ & 0.23 & 0.00 & 0.42 & 0.00 & 1.00 \\
\hline Creditor rights $(+)$ & 0.36 & 0.00 & 0.48 & 0.00 & 1.00 \\
\hline Stock market development $(+)$ & 1.13 & 1.01 & 0.66 & 0.13 & 3.17 \\
\hline Credit market development $(+)$ & 1.18 & 1.15 & 0.35 & 0.40 & 2.23 \\
\hline \multicolumn{6}{|l|}{ Panel C: Equity issues } \\
\hline Ownership concentration $(1)(\%)(+)$ & 37.39 & 33.75 & 18.83 & 0.69 & 88.94 \\
\hline Ownership concentration $(2)(\%)(+)$ & 22.37 & 18.43 & 16.45 & 0.27 & 72.82 \\
\hline Outside directors $(+)$ & 0.30 & 0.33 & 0.23 & 0.00 & 0.80 \\
\hline Board size $(-)$ & 10.59 & 9.00 & 5.38 & 3.00 & 28.00 \\
\hline CEO tenure (years) $(-)$ & 5.09 & 4.00 & 4.28 & 0.10 & 20.60 \\
\hline CEO age $(+)$ & 50.66 & 51.00 & 8.16 & 33.00 & 68.00 \\
\hline Outside CEO (-) & 0.32 & 0.00 & 0.47 & 0.00 & 1.00 \\
\hline Founder CEO $(+)$ & 0.15 & 0.00 & 0.36 & 0.00 & 1.00 \\
\hline Shareholder rights $(+)$ & 0.45 & 0.00 & 0.50 & 0.00 & 1.00 \\
\hline Creditor rights $(+)$ & 0.60 & 1.00 & 0.49 & 0.00 & 1.00 \\
\hline Stock market development $(+)$ & 1.00 & 1.04 & 0.47 & 0.23 & 2.52 \\
\hline Credit market development (+) & 1.27 & 1.48 & 0.32 & 2.23 & 0.67 \\
\hline
\end{tabular}


Table 4 (continued)

Panel D: Pairwise differences in means

Governance characteristic

CD vs. Straight Debt

CD vs. Equity

Ownership concentration (1) (\%) (+)

0.20

$-3.92 * *$

Ownership concentration (2) (\%) (+)

$-2.62 *$

$-2.45^{*}$

Outside directors $(+)$

0.02

0.02

Board size (-)

$-2.14 * * *$

$2.31 * * *$

CEO tenure (years) $(-)$

$0.71 *$

$0.82 *$

CEO age $(+)$

$-0.20$

$2.60 * * *$

Outside CEO (-)

$0.12 * * *$

0.03

Founder CEO (+)

0.01

$-0.06 * *$

Shareholder rights $(+)$

$-0.06^{*}$

$-0.27 * * *$

Creditor rights $(+)$

$-0.08 * *$

$-0.32 * * *$

Stock market development $(+)$

$-0.29 * * *$

$-0.16^{* * *}$

Credit market development (+)

0.01

$-0.09 * *$ 
Table 5

\section{Descriptive statistics for control variables}

This table reports descriptive statistics for the control variables of all companies in the convertible debt sample (panel A), straight debt sample (panel B), and equity sample (panel C). Panel D reports $t$-statistics for pairwise differences in means of the control variables between convertible debt (CD) and straight debt and convertible debt and seasoned equity issuing firms. Table 3 gives the definition and source of all variables. *, **, and *** denote significance at the $0.10,0.05$, and 0.01 levels.

\begin{tabular}{lccccc}
\hline Characteristic & Mean & Median & Std. Dev. & Min & Max \\
\hline Panel A: Convertible debt issues & & & & & \\
Stock price run-up & 0.10 & 0.05 & 0.35 & -0.46 & 2.81 \\
Financial slack/total assets & -0.02 & -0.01 & 0.10 & -0.56 & 0.35 \\
Total proceeds/market value & 0.21 & 0.13 & 0.39 & 0.0003 & 3.83 \\
Income tax/total assets & 0.01 & 0.01 & 0.03 & -0.31 & 0.11 \\
Return on assets (\%) & 2.32 & 3.49 & 10.39 & -54.44 & 31.84 \\
Short-term debt/total assets & 0.09 & 0.07 & 0.08 & 0.00 & 0.40 \\
Long-term debt/total assets & 0.24 & 0.22 & 0.15 & 0.00 & 0.71 \\
Stock return volatility & 32.13 & 30.79 & 11.44 & 4.70 & 63.28 \\
Sales growth & 0.23 & 0.06 & 1.36 & -0.91 & 17.65 \\
Total assets (millions) & 14848 & 4541 & 27465 & 33.00 & 141521 \\
Market-to-book ratio & 2.86 & 1.71 & 3.87 & 0.21 & 31.73 \\
Stock market run-up & 0.02 & 0.09 & 0.24 & -0.76 & 0.41 \\
Stock market volatility & 0.02 & 0.01 & 0.01 & 0.01 & 0.03 \\
Treasury bond yield & 3.33 & 3.25 & 0.88 & 1.54 & 5.12 \\
Leading indicator & 0.01 & 0.01 & 0.01 & -0.02 & 0.02 \\
\hline Panel B: Straight debt issues & & & & & \\
Stock price run-up & 0.03 & 0.03 & 0.14 & -0.47 & 0.66 \\
Financial slack/total assets & 0.001 & 0.004 & 0.06 & -0.52 & 0.17 \\
Total proceeds/market value & 0.11 & 0.05 & 0.21 & 0.0001 & 1.92 \\
Income tax/total assets & 0.02 & 0.02 & 0.02 & -0.05 & 0.10 \\
Return on assets (\%) & 5.66 & 5.24 & 6.07 & -54.44 & 38.61 \\
Short-term debt/total assets & 0.09 & 0.08 & 0.06 & 0.00 & 0.37 \\
Long-term debt/total assets & 0.23 & 0.21 & 0.13 & 0.00 & 0.64 \\
Stock return volatility & 25.33 & 23.79 & 8.33 & 5.86 & 61.77 \\
Sales growth & 0.11 & 0.08 & 0.24 & -0.63 & 1.43 \\
Total assets (millions) & 27233 & 14835 & 38460 & 290.00 & 244143 \\
Market-to-book ratio & 3.26 & 2.14 & 3.57 & 0.22 & 43.03 \\
Stock market run-up & 0.02 & 0.07 & 0.20 & -0.78 & 0.56 \\
Stock market volatility & 0.01 & 0.01 & 0.01 & 0.01 & 0.03 \\
Treasury bond yield & 3.64 & 3.62 & 0.94 & 1.54 & 5.14 \\
Leading indicator & 0.01 & 0.01 & 0.01 & -0.02 & 0.02 \\
\hline & & & & & \\
\hline
\end{tabular}


Table 5 (continued)

Panel C: Equity issues

Stock price run-up

Financial slack/total assets

Total proceeds/market value

Income tax/total assets

Return on assets (\%)

Short-term debt/total assets

Long-term debt/total assets

Stock return volatility

Sales growth

Total assets (millions)

Market-to-book ratio

Stock market run-up

Stock market volatility

Treasury bond yield

$\begin{array}{lcrcr}0.08 & 0.06 & 0.18 & -0.39 & 1.18 \\ -0.06 & 0.01 & 0.27 & -2.10 & 0.39 \\ 0.23 & 0.08 & 0.63 & 0.0004 & 7.06 \\ 0.01 & 0.01 & 0.03 & -0.11 & 0.15 \\ -1.89 & 4.20 & 23.35 & -168.96 & 32.11 \\ 0.06 & 0.04 & 0.07 & 0.00 & 0.37 \\ 0.17 & 0.13 & 0.17 & 0.00 & 0.65 \\ 36.68 & 32.89 & 14.84 & 8.10 & 79.07 \\ 0.17 & 0.06 & 0.79 & -0.98 & 8.41 \\ 9985 & 802 & 26270 & 1.00 & 191159 \\ 4.51 & 2.24 & 7.24 & 0.36 & 62.34 \\ 0.11 & 0.14 & 0.09 & -0.45 & 0.20 \\ 0.01 & 0.01 & 0.00 & 0.01 & 0.03 \\ 3.01 & 3.01 & 0.45 & 1.54 & 4.30 \\ 0.01 & 0.01 & 0.00 & 0.00 & 0.01\end{array}$

Panel D: Pairwise differences in means

Control Variables

CD vs. Straight Debt

CD vs. Equity

Stock price run-up

$0.06 * * *$

$-0.02 * * *$

0.02

Financial slack/total assets

Total proceeds/market value

$0.10 * * *$

$0.04 * *$

Income tax/total assets

Return on assets (\%)

Short-term debt/total assets

$-0.01 * * *$

$-0.01$

Long-term debt/total assets

$-3.32 * * *$

0.00

Stock return volatility

0.00

$4.21 * *$

0.02

$0.03 * * *$

Sales growth

$6.84 * * *$

$0.07 * * *$

Total assets (log)

$0.11 *$

$-4.54 * * *$

$-1.15^{* * *}$

0.06

Market-to-book ratio

$-0.44$

$1.83 * * *$

Stock market run-up

$-0.00$

$-1.65 * * *$

Stock market volatility

$0.00 * * *$

$-0.09 * * *$

Treasury bond yield

$-0.31 * * *$

$0.01 * * *$

Leading indicator

$0.00 * *$ 


\section{Table 6}

\section{Multinomial logistic regression analysis of the choice between convertible and straight bonds}

This table reports coefficients and $p$-values of multinomial logit regressions for the choice between convertible debt and straight debt. These pairwise regression results are the outcome of a multinomial security choice model that simultaneously incorporates the choice between convertible debt, straight debt, and equity. Regression (1) includes all the

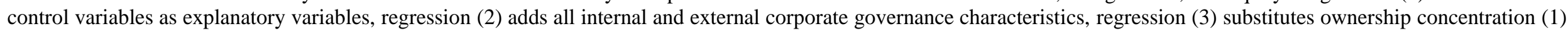
with ownership concentration (2), regression (4) adds a dummy variable to control for year clustering in 2005/2006, regression (5) adds a dummy variable to control for French

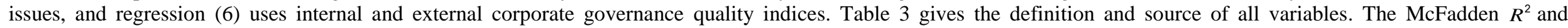

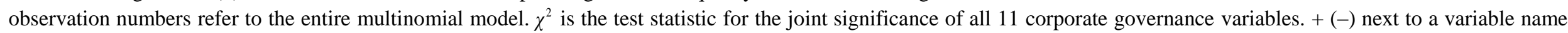
indicates it is a proxy (inverse proxy) for corporate governance quality. $*$, **, and $* * *$ denote significance at the $0.10,0.05$, and 0.01 levels.

\begin{tabular}{|c|c|c|c|c|c|c|}
\hline Variables & (1) & $(2)$ & $(3)$ & (4) & $(5)$ & (6) \\
\hline \multirow[t]{2}{*}{ Intercept } & 0.64 & 2.56 & 3.13 & 1.94 & 0.68 & -1.24 \\
\hline & $(0.57)$ & $(0.46)$ & $(0.37)$ & $(0.58)$ & $(0.85)$ & $(0.35)$ \\
\hline \multirow[t]{2}{*}{ Internal governance quality index (+) } & & & & & & $-0.29 * *$ \\
\hline & & & & & & $(0.05)$ \\
\hline \multirow[t]{2}{*}{ External governance quality index (+) } & & & & & & $-0.29 * * *$ \\
\hline & & & & & & $(0.00)$ \\
\hline \multirow{2}{*}{ Ownership concentration (1) (\%) (+) } & & $-0.02 * * *$ & & $-0.02 * * *$ & $-0.02 * * *$ & \\
\hline & & $(0.01)$ & & $(0.01)$ & $(0.01)$ & \\
\hline \multirow[t]{2}{*}{ Ownership concentration $(2)(\%)(+)$} & & & $-0.03 * * *$ & & & \\
\hline & & & $(0.00)$ & & & \\
\hline \multirow[t]{2}{*}{ Outside directors $(\%)(+)$} & & 0.05 & -0.14 & -0.10 & 0.07 & \\
\hline & & $(0.92)$ & $(0.80)$ & $(0.86)$ & $(0.90)$ & \\
\hline \multirow[t]{2}{*}{ Board size $(\log )(-)$} & & -0.02 & -0.12 & -0.06 & 0.10 & \\
\hline & & $(0.95)$ & $(0.73)$ & $(0.86)$ & $(0.78)$ & \\
\hline \multirow[t]{2}{*}{ CEO experience $(\log )(-)$} & & -0.06 & -0.05 & -0.07 & -0.09 & \\
\hline & & $(0.51)$ & $(0.63)$ & $(0.50)$ & $(0.35)$ & \\
\hline \multirow[t]{2}{*}{ CEO age $(\log )(+)$} & & -0.01 & -0.14 & -0.12 & 0.24 & \\
\hline & & $(0.99)$ & $(0.87)$ & $(0.89)$ & $(0.78)$ & \\
\hline \multirow[t]{2}{*}{ Outside CEO (-) } & & $0.49^{*}$ & $0.49^{*}$ & $0.51^{* *}$ & $0.51^{* *}$ & \\
\hline & & $(0.06)$ & $(0.06)$ & $(0.05)$ & $(0.05)$ & \\
\hline
\end{tabular}


Table 6 (continued)

Founder CEO (+)

Shareholder rights $(+)$

Creditor rights $(+$

Stock market development (+)

Credit market development (+)

Stock price run-up

Financial slack/total assets

Total proceeds/market value

Income tax/total asset

Return on assets

Short-term debt/total assets

Long-term debt/total assets

Stock return volatility

\begin{tabular}{|c|c|c|c|c|c|}
\hline & -0.64 & -0.71 & -0.76 & -0.75 & \\
\hline & $(0.18)$ & $(0.12)$ & $(0.13)$ & $(0.11$ & \\
\hline & -0.46 & -0.47 & -0.36 & -0.51 & \\
\hline & $(0.24)$ & $(0.25)$ & $(0.36)$ & $(0.21)$ & \\
\hline & $-0.78 * *$ & $-0.90 * * *$ & $-0.83 * *$ & -0.33 & \\
\hline & $(0.02)$ & $(0.01)$ & $(0.01)$ & $(0.35)$ & \\
\hline & $-1.33 * * *$ & $-1.43 * * *$ & $-1.43 * * *$ & $-1.24 * * *$ & \\
\hline & $(0.00)$ & $(0.00)$ & $(0.00)$ & $(0.00)$ & \\
\hline & $0.85 *$ & $1.04 * *$ & $0.94 * *$ & $1.36 * * *$ & \\
\hline & $(0.07)$ & $(0.03)$ & $(0.04)$ & $(0.01)$ & \\
\hline $0.94 * *$ & $1.05^{* *}$ & $1.16^{* *}$ & $0.99 * *$ & $0.94 * *$ & $1.14 * *$ \\
\hline$(0.03)$ & $(0.02)$ & $(0.03)$ & $(0.03)$ & $(0.04)$ & $(0.02)$ \\
\hline-0.12 & -0.33 & -0.22 & -0.20 & -0.13 & -0.52 \\
\hline$(0.93)$ & $(0.81)$ & $(0.87)$ & $(0.89)$ & $(0.93)$ & $(0.68)$ \\
\hline$-0.61^{*}$ & $-0.76^{* *}$ & $-0.63 * *$ & $-0.80 * *$ & $-0.67 * *$ & $-0.80 * *$ \\
\hline$(0.10)$ & $(0.02)$ & $(0.05)$ & $(0.01)$ & $(0.04)$ & $(0.02)$ \\
\hline-6.70 & -8.39 & -7.79 & $-11.40^{*}$ & -8.94 & -6.94 \\
\hline$(0.21)$ & $(0.13)$ & $(0.16)$ & $(0.08)$ & $(0.12)$ & $(0.14)$ \\
\hline-0.04 & -0.03 & -0.03 & -0.04 & -0.02 & -0.03 \\
\hline$(0.18)$ & $(0.27)$ & $(0.28)$ & $(0.22)$ & $(0.47)$ & $(0.25)$ \\
\hline 1.01 & 0.39 & 0.76 & 0.23 & 0.61 & 0.04 \\
\hline$(0.51)$ & $(0.84)$ & $(0.70)$ & $(0.90)$ & $(0.76)$ & $(0.98)$ \\
\hline $1.78 * *$ & $1.60 *$ & $1.57 *$ & $1.57 *$ & $2.01 * *$ & $1.88 * *$ \\
\hline$(0.02)$ & $(0.06)$ & $(0.07)$ & $(0.07)$ & $(0.02)$ & $(0.01)$ \\
\hline $0.05^{* * *}$ & $0.06 * * *$ & $0.06 * * *$ & $0.06 * * *$ & $0.06 * * *$ & $0.06 * * *$ \\
\hline$(0.00)$ & $(0.00)$ & $(0.00)$ & $(0.00)$ & $(0.00)$ & $(0.00)$ \\
\hline
\end{tabular}


Table 6 (continued)

Total assets $(\log )$

Market-to-book ratio

Sales growth

Stock market run-up

Stock market volatility

Treasury bond yield

Leading indicator

2005/2006 dummy

France dummy

McFadden $\mathrm{R}^{2}$

$\chi^{2}$

$\begin{array}{ccc}-0.47^{* * *} & -0.63 * * * & -0.62 * * * \\ (0.00) & (0.00) & (0.00) \\ -0.01 & -0.03 & -0.04 \\ (0.59) & (0.29) & (0.20) \\ 0.63^{*} & 0.97 * * * & 0.96 * * \\ (0.06) & (0.01) & (0.01) \\ 0.92 & 0.97 * * * & 0.61 \\ (0.31) & (0.01) & (0.53) \\ 66.22 * * & 44.88 & 39.64 \\ (0.02) & (0.17) & (0.23) \\ 0.08 & 0.43 * * & 0.46 * * \\ (0.58) & (0.03) & (0.02) \\ -15.57 & -9.59 & -7.92 \\ (0.58) & (0.75) & (0.80)\end{array}$

35.39

667

$-0.66^{* * *}$
$(0.00)$
-0.03

$-0.71 * * *$

$-0.56 * * *$

$-0.03$

(0.00)

(0.00)

(0.36)

$0.87 * *$

$-0.04$

$-0.02$

(0.02)

(0.48)

1.17

$0.85 * *$

(0.01)

$(0.02)$

(0.25)

$88.82 * *$

$(0.02)$

$0.68 * * *$

(0.00)

$-16.98$

(0.58)

$1.02 * * *$

(0.01)

0.78

0.94

(0.33)

$66.01 * *$

42.93

(0.20)

(0.03)

0.11

(0.50)

(0.04)

$-11.91$

$-14.80$

(0.61)

$1.05 * * *$

(0.00)
41.39

$82.63 * * *$

667
43.64

$80.04 * * *$

667
41.84

$57.34 * * *$

667
37.21

$24.08 * * *$ 


\section{Table 7}

\section{Multinomial logistic regression analysis of the choice between convertible debt and seasoned equity}

This table reports coefficients and $p$-values of multinomial logit regressions of the choice between convertible debt and seasoned equity. These pairwise regression results are the

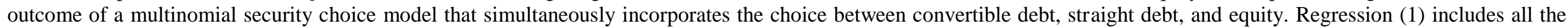
control variables as explanatory variables, regression (2) adds all internal and external corporate governance characteristics, regression (3) substitutes ownership concentration (1) with ownership concentration (2), regression (4) adds a dummy variable to control for year clustering in 2005/2006, regression (5) adds a dummy variable to control for French

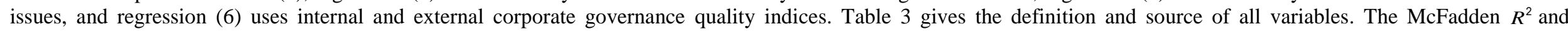

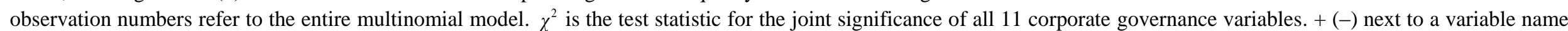
indicates it is a proxy (inverse proxy) for corporate governance quality. *, **, and *** denote significance at the $0.10,0.05$, and 0.01 levels.

\begin{tabular}{|c|c|c|c|c|c|c|}
\hline Variables & $(1)$ & $(2)$ & (3) & $(4)$ & $(5)$ & $(6)$ \\
\hline \multirow[t]{2}{*}{ Intercept } & $-13.55 * * *$ & $-16.55 * * *$ & $-16.77 * * *$ & $-11.02 * *$ & $-20.42 * * *$ & $-14.75 * * *$ \\
\hline & $(0.00)$ & $(0.00)$ & $(0.00)$ & $(0.05)$ & $(0.00)$ & $(0.00)$ \\
\hline \multirow[t]{2}{*}{ Internal governance quality index $(+)$} & & & & & & -0.11 \\
\hline & & & & & & $(0.58)$ \\
\hline External governance quality index $(+)$ & & & & & & $-0.30 * * *$ \\
\hline
\end{tabular}

Ownership concentration (1) $(\%)(+)$

\section{$-0.02 * *$}

Ownership concentration (2) (\%) (+)

Outside directors (\%) (+)

Board size $(\log )(-)$

CEO experience $(\log )(-)$

CEO age $(\log )(+)$

Outside CEO (-)

$\begin{array}{cc} & -0.02^{* *} \\ & (0.04) \\ -0.09 & -0.09 \\ (0.90) & (0.90) \\ 0.63 & 0.53 \\ (0.19) & (0.27) \\ 0.06 & 0.09 \\ (0.67) & (0.56) \\ 0.59 & 0.56 \\ (0.61) & (0.63) \\ -0.07 & -0.10 \\ (0.86) & (0.79)\end{array}$

$-0.02 * *$

(0.04)

$-0.02 *$

(0.06)

(0.00)
(0.79)
0.18

$(0.81)$

$1.02 * *$

(0.04)

0.03

(0.82)

1.09

(0.37)

$-0.08$

(0.84) 
Table 7 (continued)

Founder CEO (+)

Shareholder rights $(+)$

Creditor rights $(+$

Stock market development $(+)$

Credit market development (+)

Stock price run-up

Financial slack/total assets

Total proceeds/market value

Income tax/total assets

Return on assets

Short-term debt/total assets

Long-term debt/total assets

Stock return volatility

\begin{tabular}{|c|c|c|c|c|}
\hline-0.01 & -0.05 & -0.23 & -0.31 & \\
\hline (0.99) & $(0.92)$ & $(0.66)$ & $(0.56)$ & \\
\hline$-1.14 * *$ & $-1.12 * *$ & $-1.23 * *$ & $-1.18 * *$ & \\
\hline$(0.04)$ & $(0.04)$ & $(0.05)$ & $(0.03)$ & \\
\hline$-0.99 * *$ & $-1.02 * *$ & -0.76 & -0.40 & \\
\hline$(0.04)$ & $(0.03)$ & $(0.14)$ & $(0.43)$ & \\
\hline-0.17 & -0.22 & 0.06 & -0.09 & \\
\hline$(0.69)$ & $(0.63)$ & $(0.90)$ & $(0.85)$ & \\
\hline 0.48 & 0.57 & 0.30 & 1.33 & \\
\hline$(0.52)$ & $(0.46)$ & $(0.70)$ & $(0.10)$ & \\
\hline-0.45 & -0.51 & -0.11 & -0.29 & -0.41 \\
\hline$(0.75)$ & $(0.72)$ & $(0.92)$ & $(0.84)$ & $(0.74)$ \\
\hline-1.73 & -1.75 & -1.87 & -1.60 & -1.52 \\
\hline$(0.20)$ & $(0.21)$ & $(0.15)$ & $(0.24)$ & $(0.22)$ \\
\hline 0.13 & 0.17 & -0.02 & 0.20 & -0.04 \\
\hline$(0.79)$ & $(0.73)$ & $(0.96)$ & $(0.68)$ & $(0.93)$ \\
\hline$-15.64 * * *$ & $-15.15 * * *$ & $-15.21 *$ & $-14.79 * * *$ & $-14.53 * *$ \\
\hline$(0.01)$ & $(0.01)$ & $(0.06)$ & $(0.01)$ & $(0.03)$ \\
\hline 0.02 & 0.02 & 0.03 & 0.03 & 0.02 \\
\hline$(0.24)$ & $(0.26)$ & $(0.14)$ & $(0.17)$ & $(0.30)$ \\
\hline 0.94 & 0.84 & 0.76 & 1.48 & 2.12 \\
\hline$(0.71)$ & $(0.75)$ & $(0.77)$ & $(0.58)$ & $(0.39)$ \\
\hline $2.71 * *$ & $2.64 * *$ & $2.41^{* *}$ & $3.51 * * *$ & 1.68 \\
\hline$(0.02)$ & $(0.03)$ & $(0.05)$ & $(0.00)$ & $(0.12)$ \\
\hline 0.02 & 0.02 & 0.01 & 0.02 & 0.01 \\
\hline$(0.15)$ & $(0.14)$ & $(0.38)$ & $(0.16)$ & $(0.42)$ \\
\hline
\end{tabular}


Table 7 (continued)

Total assets $(\log )$

Market-to-book ratio

$0.28 * * *-0.10$

(0.00)

$-0.04$

(0.41)

(0.30)

0.06

$(0.47)$

Stock market run-up

Stock market volatility

$5.88 * * *$

$-0.06$

0.12

0.10

$-0.05$

$0.20 * *$

Sales growth

(0.00)

$532.14 * * *$

(0.00)

$1.72 * * *$

(0.11)

(0.29)

$-0.06^{*}$

(0.39)

$-0.05$

(0.70)

$-0.07 *$

(0.04)

(0.10)

$-0.00$

(0.93)

(0.98)

$6.72 * * *$

$6.71 * * *$

(0.00)

$573.73 * * *$

$573.99 * * *$

(0.00)

(0.00)

$(0.00)$

$-101.42 * *$

$1.94 * * *$

$1.97 * * *$

(0.00)

Leading indicator

(0.05)

$(0.00)$

$-91.75^{*}$

(0.09)

$-92.05 *$

(0.09)

$$
\text { (0.22) }
$$

$-0.03$

(0.78)

$6.64 * * *$

$$
\text { (0.00) }
$$

$302.62 * * *$

(0.00)

$1.41 * * *$

(0.00)

$-87.63 *$

(0.09)

$-2.38 * * *$

(0.00)

France dummy

$$
\text { (0.00) }
$$

McFadden $\mathrm{R}^{2}$

35.39

$\begin{array}{ll}40.58 & 41.39 \\ 75.54 * * * & 82.63 * * * \\ 667 & 667\end{array}$

43.64

$80.04 * * *$

41.84

\begin{tabular}{|c|c|c|c|c|c|c|}
\hline$\chi^{2}$ & & $75.54 * * *$ & $82.63^{* * *}$ & $80.04 * * *$ & $57.34 * * *$ & $24.08^{* * * *}$ \\
\hline$N$ & 667 & 667 & 667 & 667 & 667 & 667 \\
\hline
\end{tabular}


Table 8

\section{Logistic regression analysis of the security choice considering detailed ownership categories}

This table reports coefficients and $p$-values of multinomial logit regressions for the security choice between convertible debt (CD) and straight debt and between convertible debt and equity. Both regressions include dummy variables taking the value one if a company has a blockholder owning more than $10 \%$ of the firm's equity belonging to one of the following ten categories: banks, financial advisory firms, foundations, governments, hedge funds/private equity firms, industrials, insurance companies, management, mutual funds, and private (mostly family) owners. Table 3 gives the definition and source of all variables. $\chi^{2}$ is the test statistic for the joint significance of the 10 corporate governance variables and the 10 ownership categories. $+(-)$ next to a variable name indicates it is a proxy (inverse proxy) for corporate governance quality. *, **, and $* * *$ denote significance at the $0.10,0.05$, and 0.01 levels.

\begin{tabular}{|c|c|c|}
\hline Variables & Straight Debt & Equity \\
\hline \multirow[t]{2}{*}{ Intercept } & 2.15 & $-16.32 * * *$ \\
\hline & $(0.55)$ & $(0.00)$ \\
\hline \multirow[t]{2}{*}{ Banks } & $0.82 *$ & 0.33 \\
\hline & $(0.07)$ & $(0.59)$ \\
\hline \multirow[t]{2}{*}{ Financial advisors } & -0.40 & $-0.96 *$ \\
\hline & $(0.25)$ & $(0.06)$ \\
\hline \multirow[t]{2}{*}{ Foundations } & $-1.74 * *$ & 1.07 \\
\hline & $(0.03)$ & $(0.28)$ \\
\hline \multirow[t]{2}{*}{ Government } & $-1.25 * * *$ & $-1.41 *$ \\
\hline & $(0.01)$ & $(0.05)$ \\
\hline \multirow[t]{2}{*}{ Hedge funds/Private equity firms } & -0.46 & 0.09 \\
\hline & $(0.46)$ & $(0.90)$ \\
\hline \multirow[t]{2}{*}{ Industrials } & 0.11 & -0.12 \\
\hline & $(0.70)$ & $(0.78)$ \\
\hline \multirow[t]{2}{*}{ Insurance companies } & -0.34 & -1.46 \\
\hline & $(0.68)$ & $(0.18)$ \\
\hline \multirow[t]{2}{*}{ Management } & 0.55 & 1.67 \\
\hline & $(0.49)$ & $(0.27)$ \\
\hline \multirow[t]{2}{*}{ Mutual funds } & -0.31 & -0.77 \\
\hline & $(0.47)$ & $(0.32)$ \\
\hline \multirow[t]{2}{*}{ Private owners } & $-1.05 * * *$ & $-1.36^{* *}$ \\
\hline & $(0.01)$ & $(0.02)$ \\
\hline \multirow{2}{*}{ Outside directors $(\%)(+)$} & 0.21 & -0.17 \\
\hline & $(0.70)$ & $(0.83)$ \\
\hline \multirow{2}{*}{ Board size $(\log )(-)$} & -0.03 & 0.76 \\
\hline & $(0.94)$ & $(0.13)$ \\
\hline \multirow[t]{2}{*}{ CEO tenure $(\log )(-)$} & -0.11 & 0.02 \\
\hline & $(0.27)$ & $(0.87)$ \\
\hline \multirow[t]{2}{*}{ CEO age $(\log )(+)$} & -0.12 & 0.24 \\
\hline & $(0.89)$ & $(0.84)$ \\
\hline \multirow[t]{2}{*}{ Outside CEO (-) } & -0.61 & -0.02 \\
\hline & $(0.25)$ & $(0.98)$ \\
\hline \multirow[t]{2}{*}{ Founder CEO (+) } & $0.49 *$ & 0.04 \\
\hline & $(0.06)$ & $(0.92)$ \\
\hline \multirow[t]{2}{*}{ Shareholder rights $(+)$} & -0.66 & $-1.33 * *$ \\
\hline & $(0.10)$ & $(0.02)$ \\
\hline \multirow[t]{2}{*}{ Creditor rights (+) } & $-0.58^{*}$ & $-0.87 *$ \\
\hline & $(0.09)$ & $(0.08)$ \\
\hline \multirow[t]{2}{*}{ Stock market development (+) } & $-1.15 * * *$ & 0.08 \\
\hline & $(0.00)$ & $(0.87)$ \\
\hline
\end{tabular}


Table 8 (continued)

Credit market development (+)

$\begin{array}{cc}0.74 & 0.54 \\ (0.15) & (0.53) \\ 0.99 * & -0.56 \\ (0.07) & (0.73) \\ -0.94 & -1.99 \\ (0.53) & (0.20) \\ -0.85 * * * & 0.07 \\ (0.01) & (0.89) \\ -11.56 * & -20.88^{* *} \\ (0.08) & (0.01) \\ -0.02 & 0.03 \\ (0.40) & (0.27) \\ -0.37 & 1.08 \\ (0.86) & (0.71) \\ 1.69 * & 3.57 * * * \\ (0.07) & (0.01) \\ 0.05 * * * & 0.02 \\ (0.00) & (0.19) \\ -0.60 * * * & 0.11 \\ (0.00) & (0.39) \\ -0.02 & -0.04 \\ (0.47) & (0.26) \\ 1.03 * * * & 0.06 \\ (0.01) & (0.77) \\ 0.79 & 7.25 * * * \\ (0.45) & (0.00) \\ 55.06 & 588.82^{* * *} \\ (0.11) & (0.00) \\ 0.46 * * & 1.95 \\ (0.03) & (0.00) \\ -8.09 & -108.38 * * \\ (0.79) & (0.05) \\ 42.36 & 42.36 \\ 98.05 * * * & 98.05 * * * \\ 667 & 667 \\ & \end{array}$


Table 9

Regression analysis of stock returns around convertible debt announcements

This table reports coefficients and $p$-values of linear regressions of announcement returns of convertible debt issues. The dependent variable is the CAR (Cumulative Abnormal Return) calculated using a one factor market model over the window $(0,1)$. Company and market returns are from Datastream. Regression (1) includes all internal and external corporate governance characteristics as well as control variables. Regression (2) includes a dummy variable for callable convertibles and convertible bond delta. Table 3 gives the definition and source of all variables. $+(-)$ next to a variable name indicates it is a proxy (inverse proxy) for corporate governance quality. $* * *$, and $* * *$ denote significance at the $0.10,0.05$, and 0.01 levels.

\begin{tabular}{|c|c|c|}
\hline Variables & (1) & (2) \\
\hline \multirow[t]{2}{*}{ Intercept } & 0.12 & 0.17 \\
\hline & $(0.35)$ & $(0.25)$ \\
\hline \multirow[t]{2}{*}{ Ownership concentration $(1)(+)$} & -0.00 & -0.00 \\
\hline & $(0.31)$ & $(0.23)$ \\
\hline \multirow[t]{2}{*}{ Outside directors $(\%)(+)$} & -0.01 & -0.02 \\
\hline & $(0.65)$ & $(0.27)$ \\
\hline \multirow[t]{2}{*}{ Board size $(\log )(-)$} & 0.00 & -0.00 \\
\hline & $(0.77)$ & $(0.83)$ \\
\hline \multirow[t]{2}{*}{ CEO experience $(\log )(-)$} & 0.00 & 0.00 \\
\hline & $(0.19)$ & $(0.18)$ \\
\hline \multirow[t]{2}{*}{ CEO age $(\log )(+)$} & -0.02 & -0.02 \\
\hline & $(0.42)$ & $(0.40)$ \\
\hline \multirow[t]{2}{*}{ Outside CEO (-) } & 0.01 & 0.00 \\
\hline & $(0.37)$ & $(0.43)$ \\
\hline \multirow[t]{2}{*}{ Founder CEO $(+)$} & $-0.02 * *$ & $-0.02 * *$ \\
\hline & $(0.03)$ & $(0.02)$ \\
\hline \multirow[t]{2}{*}{ Shareholder rights $(+)$} & 0.02 & 0.02 \\
\hline & $(0.12)$ & $(0.12)$ \\
\hline \multirow[t]{2}{*}{ Creditor rights (+) } & $-0.02 *$ & $-0.02 * *$ \\
\hline & $(0.10)$ & $(0.05)$ \\
\hline \multirow[t]{2}{*}{ Stock market development (+) } & -0.01 & -0.01 \\
\hline & $(0.32)$ & $(0.21)$ \\
\hline \multirow[t]{2}{*}{ Credit market development (+) } & 0.00 & 0.01 \\
\hline & $(0.63)$ & $(0.54)$ \\
\hline \multirow[t]{2}{*}{ Stock price run-up } & 0.00 & 0.01 \\
\hline & $(0.55)$ & $(0.21)$ \\
\hline \multirow[t]{2}{*}{ Financial slack/total assets } & 0.03 & 0.05 \\
\hline & $(0.43)$ & $(0.27)$ \\
\hline \multirow[t]{2}{*}{ Total proceeds/market value } & 0.00 & -0.01 \\
\hline & $(0.43)$ & $(0.72)$ \\
\hline \multirow[t]{2}{*}{ Income tax/total assets } & 0.06 & 0.06 \\
\hline & $(0.13)$ & $(0.65)$ \\
\hline \multirow[t]{2}{*}{ Return on assets } & -0.00 & 0.00 \\
\hline & $(0.61)$ & $(0.97)$ \\
\hline \multirow[t]{2}{*}{ Short-term debt/total assets } & 0.03 & 0.01 \\
\hline & $(0.34)$ & $(0.65)$ \\
\hline \multirow[t]{2}{*}{ Long-term debt/total assets } & 0.02 & 0.01 \\
\hline & $(0.30)$ & $(0.56)$ \\
\hline \multirow[t]{2}{*}{ Stock return volatility } & -0.00 & -0.00 \\
\hline & $(0.66)$ & $(0.14)$ \\
\hline
\end{tabular}


Table 9 (continued)

Total assets (log)

\begin{tabular}{cc}
-0.00 & -0.00 \\
$(0.43)$ & $(0.28)$ \\
-0.00 & -0.00 \\
$(0.16)$ & $(0.16)$ \\
-0.00 & $-0.02^{* * *}$ \\
$(0.29)$ & $(0.01)$ \\
-0.02 & -0.03 \\
$(0.29)$ & $(0.21)$ \\
-1.27 & $-1.61^{*}$ \\
$(0.12)$ & $(0.08)$ \\
-0.00 & -0.00 \\
$(0.45)$ & $(0.39)$ \\
$1.13 *$ & 1.21 \\
$(0.08)$ & $(0.12)$ \\
& -0.00 \\
& $(0.67)$ \\
& 0.02 \\
& $(0.23)$ \\
17.10 & \\
173 & 23.76 \\
\hline
\end{tabular}

Adjusted $R^{2}$ 